\title{
Ozone production and transports in the tropical Atlantic region during the biomass burning season
}

\author{
Geert-Jan Roelofs and Jos Lelieveld \\ Institute for Marine and Atmospheric Research Utrecht, Utrecht, The Netherlands \\ Herman G. J. Smit and Dieter Kley \\ Institute for Chemistry of the Polluted Atmosphere, Jülich, Germany
}

\begin{abstract}
Tropospheric $\mathrm{O}_{3}$ distributions over the Atlantic Ocean have been calculated with a coupled chemistry-general circulation model. Photochemically produced $\mathrm{O}_{3}$, mainly from biomass burning emissions, dominates $\mathrm{O}_{3}$ abundances over the tropical Atlantic Ocean in the southern hemisphere (SH) during September/October. On the other hand, $\mathrm{O}_{3}$ of stratospheric origin strongly contributes to the tropospheric $\mathrm{O}_{3}$ column at latitudes poleward of $30^{\circ} \mathrm{S}$. Simulated tropospheric flow patterns are in good agreement with European Centre for Medium-Range Weather Forecasts analyses and trajectory studies. Tracer transports over the tropical South Atlantic Ocean are strongly influenced by wind shear between the boundary layer and the free troposphere, leading to a stratification of $\mathrm{O}_{3}$. At the surface relatively $\mathrm{O}_{3}$-poor air is transported from $\mathrm{SH}$ middle latitudes. At higher altitudes, relatively $\mathrm{O}_{3}$-rich air is transported from the African biomass burning regions between 2 and $5 \mathrm{~km}$ and from South American biomass burning regions in the mid-to-upper troposphere. The model simulates $\mathrm{O}_{3}$ production rates of $10-50$ parts per billion by volume (ppbv) $\mathrm{O}_{3} \mathrm{~d}^{-1}$ in the lower troposphere over the biomass burning regions and 2-6 ppbv $\mathrm{O}_{3} \mathrm{~d}^{-1}$ in the middle and upper troposphere. Photochemical destruction of $\mathrm{O}_{3}$ prevails in the lower troposphere over the ocean, maximizing in the African and South American outflow regions. In the northern hemisphere, in situ photochemically produced $\mathrm{O}_{3}$ dominates throughout most of the troposphere. Calculated $\mathrm{O}_{3}$ volume mixing ratios are compared with a latitude-altitude $\mathrm{O}_{3}$ distribution measured during an Atlantic ship cruise along $30^{\circ} \mathrm{W}$, between $55^{\circ} \mathrm{N}$ and $30^{\circ} \mathrm{S}$, in September/October 1988, and with ozone sonde measurements from Southern African Fire Atmospheric Research Initiative/Transport and Atmospheric Chemistry Near the Equator-Atlantic (SAFARI/TRACE A) in September/October 1992. Calculated $\mathrm{O}_{3}$ levels agree reasonably well with the ship cruise data, except for the tropical SH lower troposphere where the model significantly underestimates $\mathrm{O}_{3}$. However, modeled vertical $\mathrm{O}_{3}$ distributions are underpredicted compared to TRACE A sonde measurements. Simulated $\mathrm{O}_{3}$ columns over the ocean are somewhat lower compared to values retrieved from satellite data, in particular over the tropical Atlantic. The underestimation is probably due to the neglect of higher hydrocarbon chemistry in the model.
\end{abstract}

\section{Introduction}

Relatively high $\mathrm{O}_{3}$ levels over the southern hemisphere (SH) Atlantic Ocean in austral spring are related to biomass burning activities in South America and Africa, which maximize in the dry season [Crutzen and Andreae, 1990]. Tropospheric $\mathrm{O}_{3}$ columns retrieved from satellite data are up to 50 Dobson units (DU) [Fishman et al., 1990; Hudson et al., 1995; Kim et al., 1996]. Several studies have analyzed atmospheric transports over the SH tropical Atlantic Ocean and their influence on observed $\mathrm{O}_{3}$ distributions. On the basis of a European Centre for Medium-Range Weather Forecasts (ECMWF) meteorological analysis, Krishnamurti et al. [1993] suggested that high $\mathrm{O}_{3}$ abundances over the eastern Atlantic Ocean result from transports of biomass burning products from South America by high-altitude westerly winds as well as transports from Africa

Copyright 1997 by the American Geophysical Union.

Paper number 97JD00400.

0148-0227/97/97JD-00400\$09.00 by lower-altitude easterly winds, followed by accumulation of $\mathrm{O}_{3}$ under the influence of an anticyclone near the west coast of central Africa. On the basis of data from the measurement campaign Southern African Fire Atmospheric Research Initiative/Transport and Atmospheric Chemistry Near the Equator-Atlantic (SAFARI/TRACE A), conducted in September and October 1992, it was demonstrated that biomass burning in South America and Africa is the dominant source of $\mathrm{O}_{3}$ precursors that lead to high $\mathrm{O}_{3}$ abundances over the tropical South Atlantic Ocean. Thompson et al. [1996a] suggested that significant additional photochemical $\mathrm{O}_{3}$ formation, 1-2 DU $\mathrm{d}^{-1}$, takes place during transport over the ocean, resulting in larger $\mathrm{O}_{3}$ columns over the ocean than over land. On the basis of a passive tracer simulation, Krishnamurti et al. [1993] proposed that transports of $\mathrm{O}_{3}$ from stratospheric origin may also contribute significantly to tropospheric $\mathrm{O}_{3}$ levels at middle latitudes.

Although several measurement series of surface $\mathrm{O}_{3}$ and vertical profiles are available for background and polluted con- 
tinental conditions, especially in the northern hemisphere (NH) [Komhyr et al., 1989; Oltmans and Levy, 1994] (World Ozone Data Center [see, e.g., Logan, 1994]), measurements of tropospheric $\mathrm{O}_{3}$ over the remote oceans for longer periods of time are rather scarce. Winkler [1988] compiled a climatology of surface $\mathrm{O}_{3}$ mixing ratios over the Atlantic Ocean from measurements carried out between 1977 and 1986 on board several research vessels. The total ozone mapping spectrometer (TOMS) minus stratospheric aerosol and gas experiment (SAGE) satellite retrieval of tropospheric $\mathrm{O}_{3}$ columns by Fishman et al. [1990] provides valuable information on the horizontal distribution of tropospheric $\mathrm{O}_{3}$. However, these data are subject to considerable uncertainty, especially for the extratropics. Further, Hudson et al. [1995] showed that thus retrieved tropospheric $\mathrm{O}_{3}$ columns are overestimated when stratocumulus clouds are present and underestimated under cloud-free conditions when the lower troposphere contains large amounts of $\mathrm{O}_{3}$. Both situations are common in the considered area.

Incidental measurement campaigns investigated $\mathrm{O}_{3}$ distributions or concentrations for a limited period. Detailed vertical distributions of tropospheric $\mathrm{O}_{3}$ were measured on board the German research vessel Polarstern. Ozone soundings were launched during ship cruises along the $30^{\circ} \mathrm{W}$ meridian between approximately $55^{\circ} \mathrm{N}$ and $30^{\circ} \mathrm{S}$ in March/April 1987 and September/October 1988 [Smit et al., 1989, 1990]. Similar cruises have been carried out closer to the Atlantic coasts [Weller et al., 1996]. Because instantaneous distributions were measured, details were strongly influenced by synoptic meteorological features, and their representativeness of monthly or seasonal distributions may be limited. Recently, a special issue of Journal of Geophysical Research, 101(D19), 1996, appeared on the SAFARI/TRACE A measurement campaign conducted in September/October 1992. The goal of the SAFARI campaign, conducted in southern Africa, was a comprehensive study of trace gas and aerosol emissions from vegetation fires and the role of fires in atmospheric chemistry, climate, and ecology [Lindesay et al., 1996]. During TRACE A the chemical composition, transport, and chemistry of the atmosphere over the tropical South Atlantic Ocean and the adjacent South American and African continents were studied [Fishman et al., 1996a]. TRACE A measurements included vertical $O_{3}$ profiles from ozone sondes, in situ measurements of various organic and inorganic trace species from aircraft, and $\mathrm{O}_{3}$ column measurements from satellite.

The current study reexamines the influence of biomass burning over the tropical Atlantic domain, as performed previously by Krishnamurti et al. [1993, 1996] and Thompson et al. [1996a] by different methods. We extend these studies toward higher latitudes in both hemispheres and use our model to quantify the relative contributions by stratosphere-troposphere exchange (STE) and in situ photochemical $\mathrm{O}_{3}$ formation in the troposphere. We use a coupled chemistry-general circulation model, which calculates background $\mathrm{CH}_{4}-\mathrm{CO}-\mathrm{NO}_{\mathrm{x}}-\mathrm{HO}_{\mathrm{x}}$ tropospheric chemistry and global meteorology on a T30 resolution $\left(3.75^{\circ} \times 3.75^{\circ}\right.$, with a time step of $\left.1800 \mathrm{~s}\right)$ with a direct coupling between chemical and meteorological simulations, for example, of cloud and boundary layer processes. Previously, the performance of the model was evaluated by comparing the simulated tropospheric $\mathrm{O}_{3}$ climatology with long-term measurements of surface $\mathrm{O}_{3}$ concentrations, $\mathrm{O}_{3}$ vertical profiles, and the tropospheric $\mathrm{O}_{3}$ columns derived from satellite data [Roelofs and Lelieveld, 1995, 1997]. In this work we examine the representativeness of the calculated $\mathrm{O}_{3}$ distributions over the tropical Atlantic Ocean during the biomass burning season and analyze the transports and chemistry simulated by the model. Section 2 gives a brief description of the model. In section 3 , calculated $\mathrm{O}_{3}$ levels are compared with the surface $\mathrm{O}_{3}$ climatology of Winkler [1988], the September/October 1988 latitudealtitude $\mathrm{O}_{3}$ distribution by Smit et al. [1990], and ozone sonde measurements from TRACE A [Thompson et al., 1996a] to validate the model. In section 4 , we analyze the influence of the governing horizontal and vertical air motions on $\mathrm{O}_{3}$ distributions over the (sub) tropical SH Atlantic Ocean and the relative role of STE. Section 5 focuses on $\mathrm{O}_{3}$ production and destruction in the tropical South Atlantic Ocean region. The conclusions are presented in Section 6.

\section{Model Description}

The general circulation model (GCM) used in this study is the 19-layer European Center Hamburg Model, version 4 (ECHAM4). In the T30 version, which is used in this study, the horizontal resolution is approximately $3.75^{\circ} \times 3.75^{\circ}$, and the time resolution is $1800 \mathrm{~s}$. The model uses 19 vertical layers in a hybrid $\sigma-p$ coordinate system, from the surface to $10 \mathrm{hPa}$. Average pressure levels relevant for the troposphere and lower stratosphere are 990, 970, 950, 900, 840, 760, 670, 580, 490, 400, $320,250,190,140,100$, and $75 \mathrm{hPa}$, referring to approximate midlayer altitudes of $0.03,0.14,0.38,0.78,1.4,2.1,3.1,4.2,5.6$, $7.0,8.6,10.2,11.9,13.8,15.9$, and $18.0 \mathrm{~km}$ above the surface, respectively. Tracer transport is calculated using a semiLagrangian advection scheme [Rasch and Williamson, 1990]. Additional vertical transports are included through parameterizations for vertical diffusion and convection [Roeckner et al., 1996; Tiedtke, 1989]. An elaborate description of ECHAM and the simulated climate is given by Roeckner et al. [1995], Chen and Roeckner [1996], and Haskins et al. [1995]. The GCM has previously been used for tracer transport studies [Feichter et al., 1991; Brost et al., 1991] and a simulation of the global sulfur cycle [Feichter et al., 1996]. For this study, it is coupled to a tropospheric chemistry model that considers background $\mathrm{CH}_{4}$ $\mathrm{CO}-\mathrm{NO}_{\mathrm{x}}-\mathrm{HO}_{\mathrm{x}}$ chemistry, emissions of $\mathrm{NO}$ and $\mathrm{CO}$, dry deposition of $\mathrm{O}_{3}, \mathrm{NO}_{2}, \mathrm{HNO}_{3}$, and $\mathrm{H}_{2} \mathrm{O}_{2}$, and wet deposition of $\mathrm{HNO}_{3}$ and $\mathrm{H}_{2} \mathrm{O}_{2}$. Concentration changes due to chemical reactions are calculated explicitly for all species by means of an Eulerian Backward Iterative (EBI) scheme. A detailed description and analysis of the coupled chemistry GCM is given by Roelofs and Lelieveld [1995, 1997].

The model considers a biomass burning source for NO of 6 $\mathrm{Tg} \mathrm{N} \mathrm{yr}{ }^{-1}$ and for $\mathrm{CO}$ of $700 \mathrm{Tg} \mathrm{CO} \mathrm{yr}{ }^{-1}$, distributed according to Hao and Liu [1994]. NO emissions from soils and from lightning play an additional role in the tropical tropospheric $\mathrm{O}_{3}$ budget. Their respective sources in the model are $5.5 \mathrm{Tg} \mathrm{N}$ $\mathrm{yr}^{-1}$, distributed according to Yienger and Levy [1995], and $5 \mathrm{Tg}$ $\mathrm{N} \mathrm{yr}^{-1}$, parameterized according to Price and Rind [1992]. Further, the model considers global NO emissions from fossil fuel burning (21 $\mathrm{Tg} \mathrm{N} \mathrm{yr}^{-1}$ [Benkovitz et al., 1996]), and $\mathrm{CO}$ emissions from fossil fuel burning (450 $\mathrm{Tg} \mathrm{CO} \mathrm{\textrm {yr } ^ { - 1 }}$ ), vegetation (100), formation from natural (280) and anthropogenic (300) higher hydrocarbons, oceans (40), and wildfires (30). CO emissions are distributed according to Lelieveld and van Dorland [1995]. Total NO and CO emissions considered in the model are $37.5 \mathrm{Tg} \mathrm{N} \mathrm{yr}^{-1}$ and $1900 \mathrm{Tg} \mathrm{CO} \mathrm{yr}^{-1}$, consistent with Intergovernmental Panel on Climate Change (IPCC) [1994]. In view of the relatively long lifetime of $\mathrm{CH}_{4}$ we prescribe $\mathrm{CH}_{4}$ 


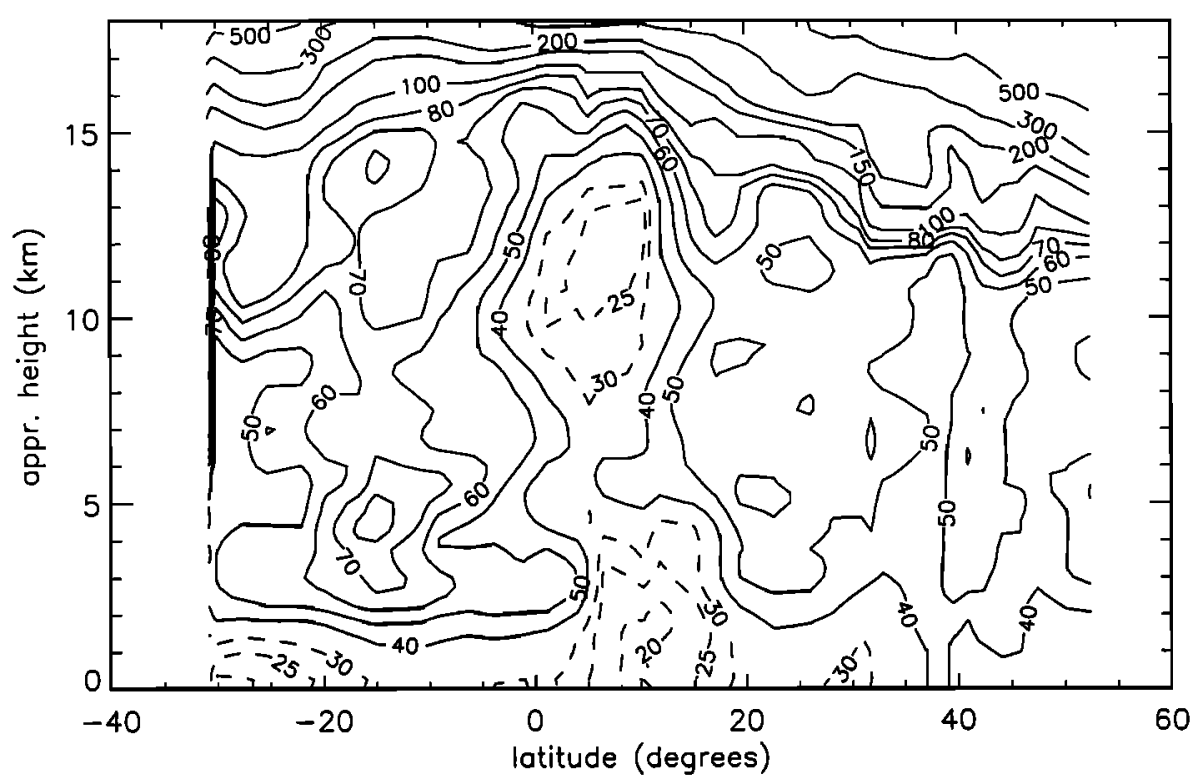

Figure 1. Tropospheric distribution of $\mathrm{O}_{3}$ mixing ratios (parts per billion by volume (ppbv)) along $30^{\circ} \mathrm{W}$, measured aboard the research vessel Polarstern in September/October 1988 [Smit et al., 1990, 1991].

surface concentrations of $1772 \mathrm{ppm}$ in the NH and 1680 in the SH [Lowe et al., 1994].

The parameterization for the dry deposition of $\mathrm{O}_{3}, \mathrm{NO}_{x}$, and $\mathrm{HNO}_{3}$ is described by Ganzeveld and Lelieveld [1995]. It derives aerodynamic and stomatal resistances directly from parameters calculated by ECHAM4. The wet scavenging of $\mathrm{HNO}_{3}$ and $\mathrm{H}_{2} \mathrm{O}_{2}$ is calculated using the large scale and convective cloud and precipitation properties calculated on-line by the climate model as described by Roelofs and Lelieveld [1995]. Stratospheric $\mathrm{O}_{3}$ concentrations are prescribed between 1 and 2 model layers above the tropopause up to $10 \mathrm{hPa}$, the top level of the GCM. Transports of $\mathrm{O}_{3}$ across the tropopause depend directly on the air motions simulated by the GCM. The simulated tropopause is marked by a potential vorticity of $3.510^{-6}$ $\mathrm{K} \mathrm{m}^{2} \mathrm{~kg}^{-1} \mathrm{~s}^{-1}$ poleward of $20^{\circ}$ latitude [Hoerling et al., 1993] and by a $-2 \mathrm{~K} \mathrm{~km}^{-1}$ temperature lapse rate equatorward of $20^{\circ}$ latitude.

Evaluation of the calculated $\mathrm{O}_{3}$ climatology shows that the model realistically represents the seasonal variability of the $\mathrm{O}_{3}$ photochemical production and of $\mathrm{O}_{3}$ transport from the stratosphere. The model successfully reproduces surface $\mathrm{O}_{3}$ concentration patterns measured in remote and relatively clean conditions but appears to underestimate $\mathrm{O}_{3}$ concentrations in polluted regions due to the neglect of higher hydrocarbon chemistry [Roelofs and Lelieveld, 1997].

Apart from $\mathrm{O}_{3}$, the chemical model considers a tracer for $\mathrm{O}_{3}$ that originates from the stratosphere, referred to as $\mathrm{O}_{3} s$, as described by Roelofs and Lelieveld [1997]. In the stratosphere, $\mathrm{O}_{3} \mathrm{~S}$ is treated in the same way as $\mathrm{O}_{3}$. It is transported from the stratosphere into the troposphere along with the calculated air motions. In the troposphere, $\mathrm{O}_{3} s$ is subject to photochemical destruction by the same reactions that destroy $\mathrm{O}_{3}$, that is, with $\mathrm{OH}, \mathrm{HO}_{2}$, and through photodissociation followed by $\mathrm{OH}$ production, but not to photochemical production. It is also removed by dry deposition. The difference between the concentrations of $\mathrm{O}_{3}$ and $\mathrm{O}_{3} \mathrm{~s}$ is a measure for $\mathrm{O}_{3}$ that originates from photochemistry in the troposphere, referred to as $\mathrm{O}_{3} t$. It must be noted that $\mathrm{O}_{3} \mathrm{~s}$ and $\mathrm{O}_{3} t$ are coupled to a certain degree because other trace gas concentrations and the insolation intensity codetermine the $\mathrm{O}_{3}$ concentration. STE intensity fluctuations that affect tropospheric $\mathrm{O}_{3} s$ levels directly are partly compensated through photochemical production of $\mathrm{O}_{3} t$ or destruction of $\mathrm{O}_{3} s$ and $\mathrm{O}_{3} t$. However, the chemical lifetime of $\mathrm{O}_{3}$ in the troposphere varies between a few days in the lower tropical troposphere and a few weeks to a few months in high latitudes. This is generally longer than the timescales of transport processes in the troposphere, which are of the order of hours, for example, for convection, to a week for synoptic scale disturbances. Thus modeled $\mathrm{O}_{3}, \mathrm{O}_{3} s$, and $\mathrm{O}_{3} t$ fields provide an appropriate analytical tool to assess the influence of chemistry and transports within the troposphere and between the stratosphere and the troposphere.

The specific contribution of biomass burning emissions on tropospheric $\mathrm{O}_{3}$ cannot be calculated directly because the model does not consider separate emission sources in the photochemical calculations. However, biomass burning contributes more than $80 \%$ of the total NO emissions in the tropical Atlantic region in the dry season, while the remainder is largely due to natural sources, that is, soils and lightning. Biomass burning therefore dominates photochemical $\mathrm{O}_{3}$ production in the region of interest.

\section{Comparison of Simulated and Measured $\mathrm{O}_{3}$ \\ 3.1. Comparison of Model Results and Ship Cruise Measurements}

A total of 40 ozone soundings were launched on a ship cruise from Bremerhaven, Germany $\left(53^{\circ} \mathrm{N}\right)$, to Rio Grande del Sol, Brazil (32 $2^{\circ}$ ), between September 15 and October 9, 1988, with a latitudinal resolution between $1.5^{\circ}$ and $2.5^{\circ}$. Figure 1 shows the measured latitudinal and vertical distribution of tropospheric $\mathrm{O}_{3}$ [Smit et al., 1990, 1991], processed with an improved background signal correction [Smit et al., 1994].

The measurements show a column of $\mathrm{O}_{3}$-low air around $10^{\circ} \mathrm{N}$, where the intertropical convergence zone (ITCZ) is located. Similar low- $\mathrm{O}_{3}$ areas are found in the tropical Indian 


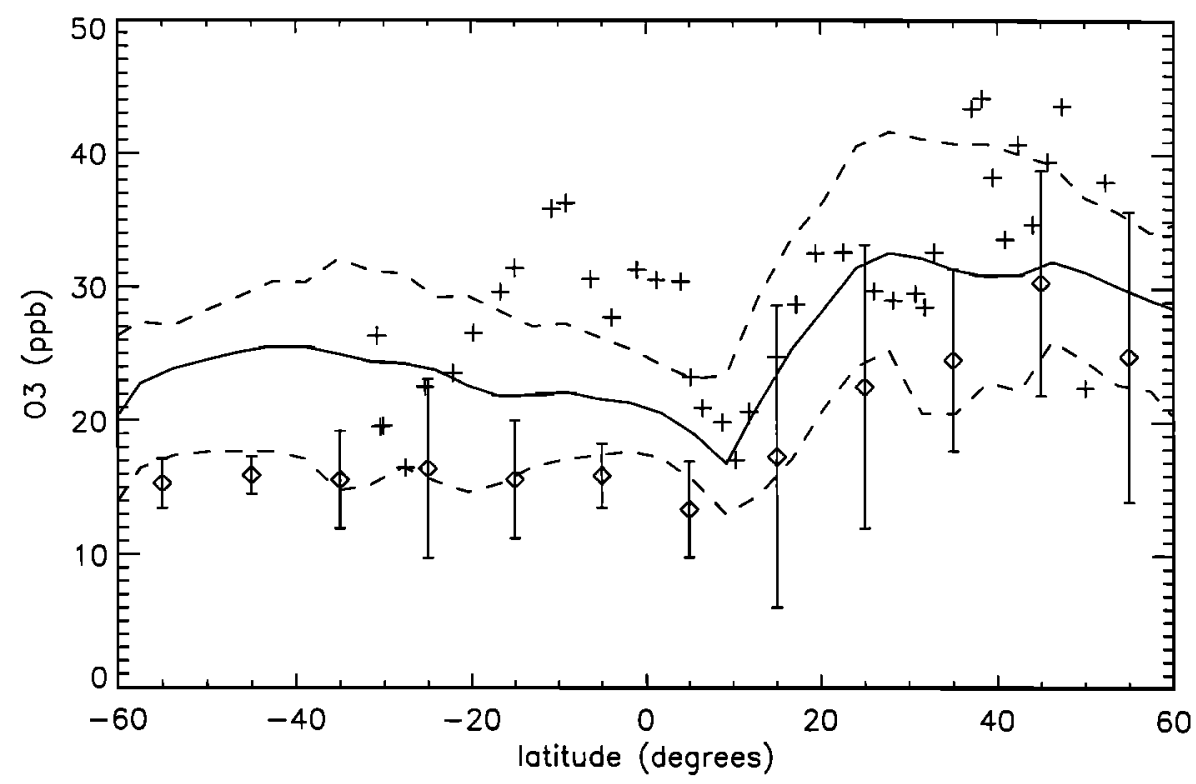

Figure 2. Surface $\mathrm{O}_{3}$ mixing ratios (ppbv) along $30^{\circ} \mathrm{W}$ derived from ozone sondes [Smit et al., 1990, 1991] (plusses), from the climatology of Winkler [1988] (diamonds, bars represent 2 standard deviations), and simulated by the model for September/October (solid line, dotted lines represent 2 standard deviations).

and Pacific Oceans [e.g., Fishman et al., 1990]. Photochemical destruction of $\mathrm{O}_{3}$ prevails at the ocean surface due to high insolation and high water vapor concentrations. Convection, connected with the upward branch of the Hadley circulation, efficiently transports the $\mathrm{O}_{3}$-depleted air upward. The tropical tropopause is located at approximately $16 \mathrm{~km}$ altitude, and the subtropical tropopause "breaks" can be identified at about $20^{\circ}-30^{\circ}$ latitude in both hemispheres [Smit et al., 1990]. The $\mathrm{NH}$ and $\mathrm{SH}$ subtropical regions are characterized by downward transport of $\mathrm{O}_{3}$-rich air from the upper troposphere. The areas of relatively high $\mathrm{O}_{3}$ between 10 and $13 \mathrm{~km}$ at $15^{\circ}-5^{\circ} \mathrm{S}$, between 6 and $12 \mathrm{~km}$ at $20^{\circ} \mathrm{N}$, and between 5 and $10 \mathrm{~km}$ at $45^{\circ}$ are characterized by relatively low water vapor concentrations, which indicates that the air may have originated from the stratosphere [Smit et al., 1990]. On the other hand, the $\mathrm{O}_{3}$ high between $5^{\circ}$ and $20^{\circ} \mathrm{S}$ in the lower troposphere is believed to originate from photochemical production associated with biomass burning emissions. This is also suggested by enhanced surface concentrations of nonmethane hydrocarbons and $\mathrm{HNO}_{3}$, measured on the same cruise [Koppmann et al., 1992; Papenbrock et al., 1992].

Qualitatively, the distribution in Figure 1 is highly similar to climatological, zonally averaged $\mathrm{O}_{3}$ distributions that result from model simulations [Roelofs and Lelieveld, 1995; World Meteorological Organization (WMO), 1995] or from a compilation of observations [Crutzen, 1995]. Nevertheless, it must be kept in mind that Figure 1 refers to an instantaneous distribution, with influences from instantaneous wind fields, the location and intensity of the ITCZ, and changes of synoptic scale characteristics between soundings, which characterize a specific meteorological situation at the time of the cruise. The potential variability of $\mathrm{O}_{3}$ over the middle Atlantic Ocean is illustrated by comparing Figure 1 with similar distributions measured on ship cruises [Smit et al., 1991; Weller et al., 1996].

The model simulations do not describe a particular year but rather an "average" meteorology. Therefore a direct comparison of the measured distribution with model results is of limited use. Instead, we use model results for September and
October of 2 subsequent model years and include the modeled variability of $\mathrm{O}_{3}$ mixing ratios in the comparison. Figure 2 shows calculated surface $\mathrm{O}_{3}$ mixing ratios for $30^{\circ} \mathrm{W}$, averaged over the $2 \times 2$ months. The model variability is indicated by the standard deviation. Also shown are the Atlantic Ocean surface $\mathrm{O}_{3}$ climatology, averaged over September and October and including the standard deviation, obtained by Winkler [1988], and the surface mixing ratios derived from the individual vertical profiles obtained during the Polarstern cruise [Smit et al., 1990].

For NH (sub) tropical latitudes there is good agreement between the calculated and the Polarstern surface concentrations. The model somewhat underestimates $\mathrm{O}_{3}$ at middle and higher latitudes. The $\mathrm{O}_{3}$ minimum near $10^{\circ} \mathrm{N}$ matches the observations, indicating that the location of the ITCZ is simulated accurately. A major discrepancy is found in the SH tropics, where the Polarstern measurements indicate a distinct local surface $\mathrm{O}_{3}$ maximum of about 35 parts per billion by volume (ppbv) at $10^{\circ} \mathrm{S}$, attributed to biomass burning activities. The model does not capture this feature. Qualitatively, the calculated $\mathrm{O}_{3}$ surface distribution agrees relatively well with the surface $\mathrm{O}_{3}$ climatology of Winkler [1988], with highest concentrations in the $\mathrm{NH}$, a minimum around $10^{\circ} \mathrm{N}$ connected with the ITCZ, and higher concentrations again in the SH. However, the calculated values are systematically about $5 \mathrm{ppbv}$ higher, and the simulated variability is smaller than measured in the NH and larger in the SH. Note that the Polarstern measurements in the $\mathrm{NH}$ are also relatively high compared to the distribution of Winkler [1988]. Ozone increases over Europe and the eastern United States have been relatively small since 1980 , that is, over the period between these measurements [Logan, 1994]. Therefore the differences probably do not result from increased anthropogenic emissions of $\mathrm{O}_{3}$ precursors from adjacent continents. An explanation may be that the Winkler [1988] measurements were not subject to absolute calibration and a systematic offset cannot be ruled out.

Figure 3 shows the simulated and measured latitudinal $\mathrm{O}_{3}$ distribution at selected altitudes. The simulated temporal vari- 

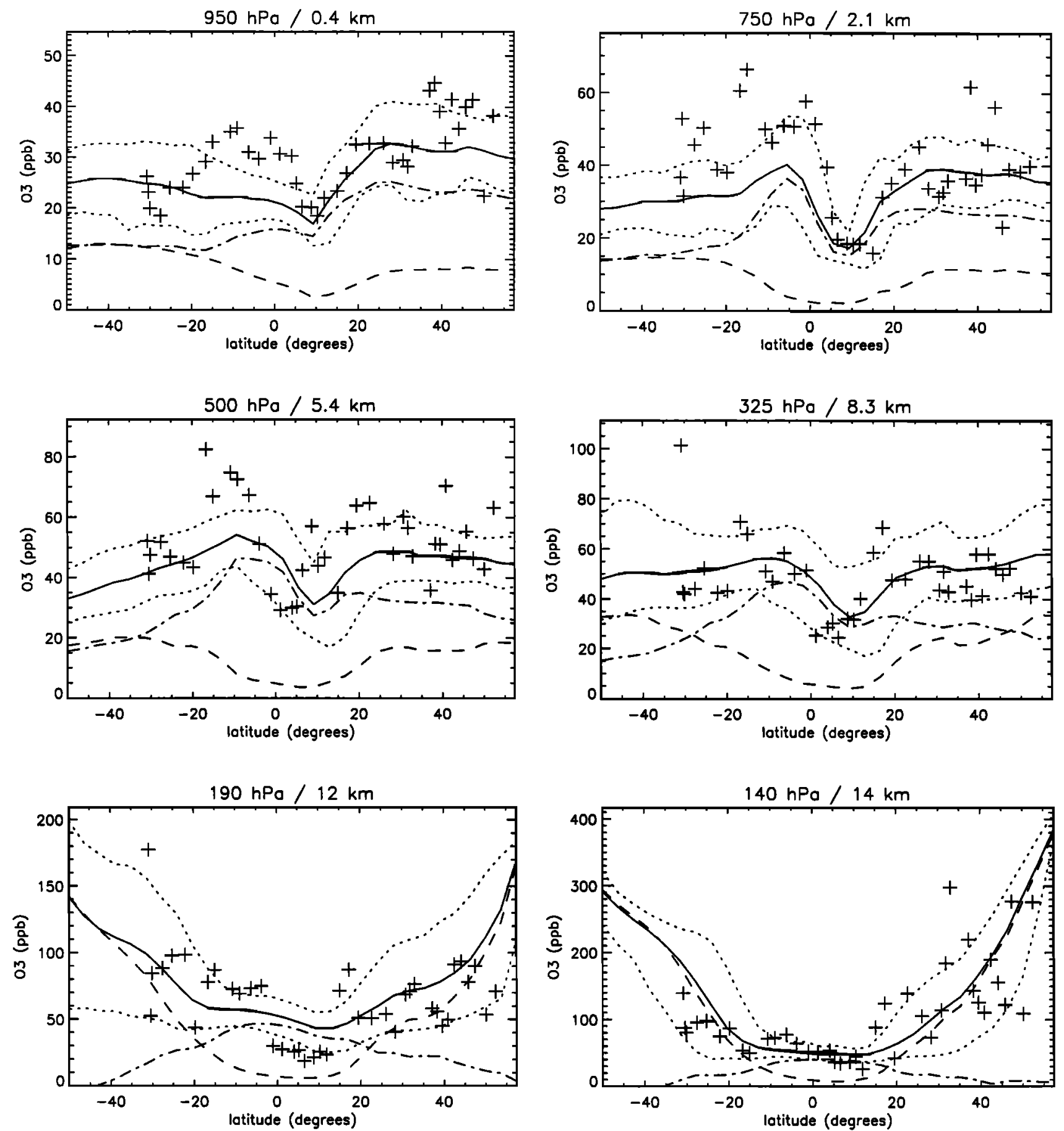

Figure 3. $\mathrm{O}_{3}$ mixing ratios (ppbv) at selected altitudes along $30^{\circ} \mathrm{W}$ from ozone sondes [Smit et al., 1990, 1991] (plusses) and simulated by the model for September/October (solid lines, dotted lines represent the 90-percentile interval). Also shown are the contributions by $\mathrm{O}_{3} s$ (dashed lines) and $\mathrm{O}_{3} t$ (dash-dotted lines).

ability is illustrated by the 90 -percentile range. The figure also shows the average contributions of photochemically produced $\mathrm{O}_{3}\left(\mathrm{O}_{3} t\right)$ and $\mathrm{O}_{3}$ of stratospheric origin $\left(\mathrm{O}_{3} s\right)$. The 90percentile range of the modeled $\mathrm{O}_{3}$ agrees reasonably well with the measured concentrations and their inherent variability throughout the $\mathrm{NH}$ and in the middle and upper $\mathrm{SH}$ troposphere, as well as in the lower stratosphere at middle latitudes. However, a significant discrepancy between model and measurements exists for the SH lower troposphere below $6 \mathrm{~km}$. The observed $\mathrm{O}_{3}$ maximum between approximately $0^{\circ}$ and $30^{\circ} \mathrm{S}$ is only partly captured by the model at 2.1 and $5.4 \mathrm{~km}$ and not at all at lower altitudes (cf. Figure 2). Our results indicate that $\mathrm{O}_{3}$ from the stratosphere (dashed lines) is relatively unimportant in this region compared to photochemically produced $\mathrm{O}_{3}$ (dash-dotted lines in Figure 3). In the lower tropical troposphere, high insolation and water vapor concentrations lead to efficient photochemical destruction of $\mathrm{O}_{3}$ from the stratosphere, while relatively high $\mathrm{O}_{3}$ levels are photochemically produced as a result of biomass burning emissions. From this we conclude that the $\mathrm{O}_{3}$ underestimation by the model results 
(a)

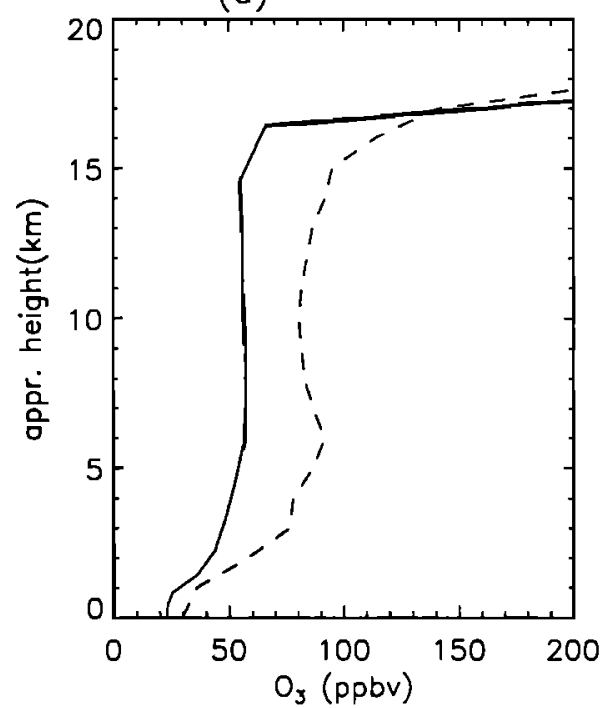

(c)

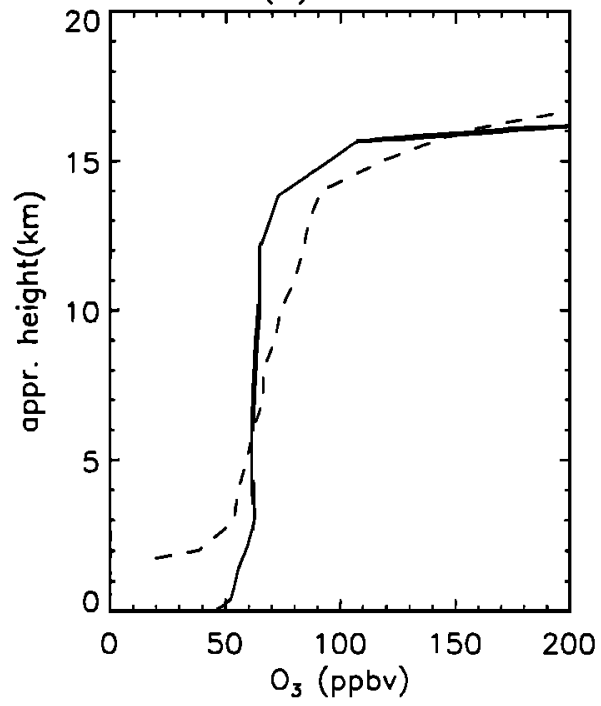

(b)

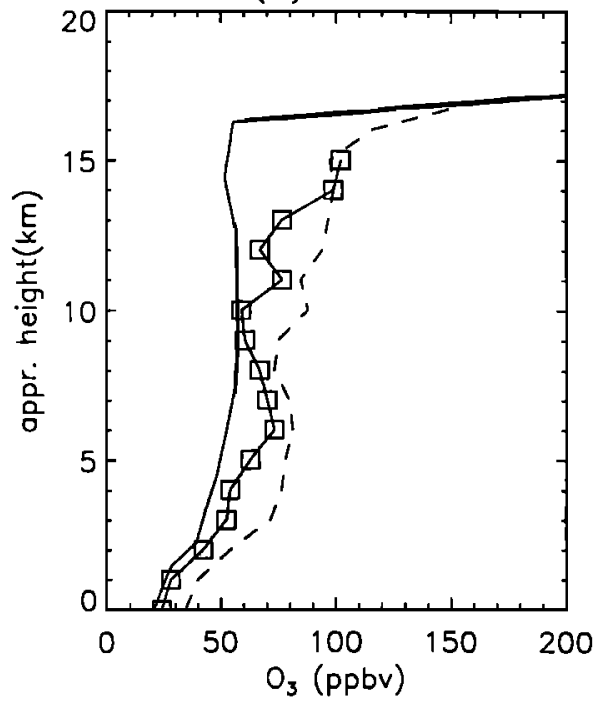

(d)

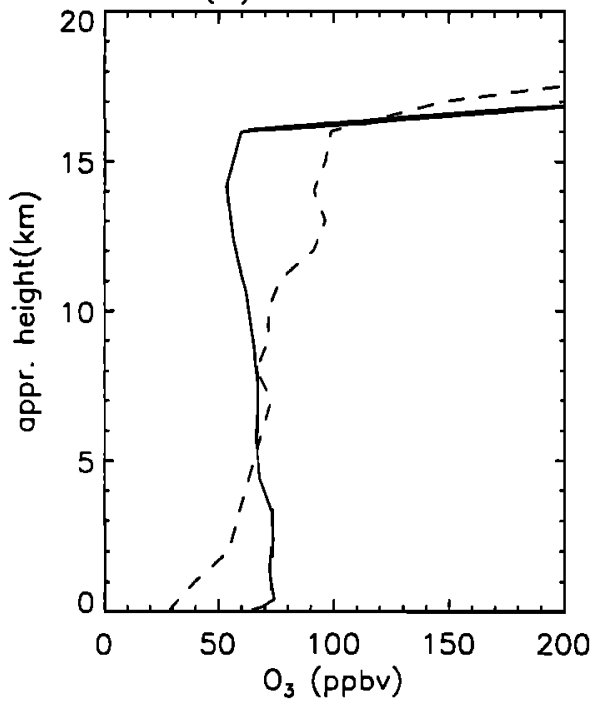

Figure 4. Simulated $\mathrm{O}_{3}$ (ppbv) for grid cells representing (a) Ascencion Island $\left(8^{\circ} \mathrm{S}, 14^{\circ} \mathrm{W}\right.$ ), (b) Natal, Brazil $\left(5^{\circ} \mathrm{S}, 35^{\circ} \mathrm{W}\right)$, (c) Irene, South Africa $\left(26^{\circ} \mathrm{S}, 28^{\circ} \mathrm{E}\right)$, and (d) Brazzaville, Congo $\left(4^{\circ} \mathrm{S}, 15^{\circ} \mathrm{E}\right)$. Vertical $\mathrm{O}_{3}$ profiles measured during TRACE A [Kirchhoff et al., 1996; Diab et al., 1996; Thompson et al., 1996a] are given by the dashed lines; the Natal September climatological average is denoted by squares [Kirchhoff et al., 1996].

from inefficient photochemical buildup from biomass burning emissions, rather than from an underestimation of STE. A significant part of biomass burning emissions consists of nonmethane hydrocarbons [e.g., Crutzen, 1995; Talbot et al., 1996] which enhance photochemical $\mathrm{O}_{3}$ production, whereas the model only considers background $\mathrm{CH}_{4}-\mathrm{CO}-\mathrm{NO}_{x}-\mathrm{HO}_{x}$ chemistry. However, it cannot be ruled out that specific meteorological conditions have influenced the measured $\mathrm{O}_{3}$ distribution in the lower troposphere, which have not been captured by our climate model. Regional transport and mixing processes may improve by applying dynamical adjustment techniques on the basis of ECMWF-analyzed meteorology [Jeuken et al., 1996], which we have planned for the future. In section 4 the transport patterns simulated by the GCM will be analyzed in more detail.

Between $0^{\circ}$ and $10^{\circ} \mathrm{N}$ the model overpredicts $\mathrm{O}_{3}$ at $12 \mathrm{~km}$. This is the region of the ITCZ, characterized by upward convective transports. The model results indicate that photochem- ically produced $\mathrm{O}_{3}$ dominates here over $\mathrm{O}_{3}$ from the stratosphere. At this altitude the model vertical resolution is relatively low ( $2 \mathrm{~km}$ around the tropical tropopause), resulting in less accurate chemical transports and artificially enhanced vertical mixing of $\mathrm{O}_{3}$ precursors. Further, the effect of heterogeneous photochemical destruction of $\mathrm{O}_{3}$, not considered by the model, may be significant in the tropics [Lelieveld and Crutzen, 1990]. On the other hand, just below the tropopause at $14 \mathrm{~km}$, the agreement between measured and modeled concentrations is good. In the $\mathrm{NH}$ lower troposphere in the vicinity of $40^{\circ} \mathrm{N}$ the underestimation of modeled $\mathrm{O}_{3}$ may be related to the neglect of higher hydrocarbon chemistry, although the effect seems to be smaller compared to the biomass burning plume, as discussed earlier. It must be noted that north of $40^{\circ} \mathrm{N}$ the Polarstern route curves toward the European continent and thus it is closer to the pollutant sources where $\mathrm{O}_{3}$ concentrations are higher. 


\subsection{Comparison of Modeled $\mathrm{O}_{3}$ and SAFARI/TRACE $A$}

\section{Measurements}

Figure 4 shows simulated vertical $\mathrm{O}_{3}$ concentration profiles for four locations in the SH Atlantic Ocean region, averaged over the $2 \times 2$ months. The figure also shows average profiles measured during SAFARI/TRACE A [from Kirchhoff et al., 1996; Diab et al., 1996; Thompson et al., 1996a]. The model appears to underestimate $\mathrm{O}_{3}$ at Ascencion and Natal. Qualitatively, the gradient between the surface and $2 \mathrm{~km}$ altitude of the Ascencion and Natal vertical profiles is captured by the model. At Ascencion the model reproduces the $\mathrm{O}_{3}$ maximum between 2 and $7 \mathrm{~km}$ altitude, associated with westward transport of air from African biomass burning regions, and somewhat lower concentrations in the upper troposphere, associated with advection from South American biomass burning areas (transports will be discussed in section 4.2). However, absolute $\mathrm{O}_{3}$ concentrations are underestimated by $20-40 \mathrm{ppbv}$ throughout the troposphere. It should be noted that satellitederived $\mathrm{O}_{3}$ columns at Ascencion and Natal measured during TRACE A are significantly larger than climatological $\mathrm{O}_{3}$ columns [Fishman et al., 1996b], indicating that 1992 was anomalous in this respect. Also, vertical $\mathrm{O}_{3}$ profiles measured at Natal during TRACE A show significantly higher concentrations than the Natal September climatological average, as shown by the squares in Figure 4 [Kirchhoff et al., 1996]. This is probably due to an unusually active period for convection and upper tropospheric $\mathrm{O}_{3}$ formation [Pickering et al., 1996; Kirchhoff et al., 1996]. Owing to the relatively coarse model resolution, the local orography at Irene is not well represented in the model. The vertical concentration gradient in the model at Irene is weaker than measured, leading to an underestimation of the $\mathrm{O}_{3}$ levels in the middle and upper troposphere. We calculate a negative $\mathrm{O}_{3}$ lapse rate at Brazzaville, in contrast to the measured profiles. This may be due to specific local, subgrid scale conditions (e.g., convection) that are not captured by the model. The model grid representing Brazzaville is located at the African continental outflow region, where convective transports do not penetrate the upper troposphere (section 4.2). Overall, the model somewhat underestimates the tropospheric $\mathrm{O}_{3}$ column, while the tropopause heights are represented relatively well at these sites.

\section{Modeled $\mathrm{O}_{3}$ Distribution Over the Southern Atlantic Ocean}

\subsection{Distribution of $\mathrm{O}_{3}$}

Figure 5 shows the simulated tropospheric $\mathrm{O}_{3}$ columns (DU) over the (sub) tropical Atlantic region, averaged over (two times) September and October. Also shown are the contributions of $\mathrm{O}_{3}$ from the stratosphere $\left(\mathrm{O}_{3} s\right)$ and $\mathrm{O}_{3}$ that is photochemically produced in the troposphere $\left(\mathrm{O}_{3} t\right)$. In this section we will shortly describe the calculated distributions; a comparison with satellite data [Fishman et al., 1990; Hudson et al., 1995] is presented by Roelofs and Lelieveld [1997].

Stratospheric $\mathrm{O}_{3}$ enters the troposphere at middle and high latitudes through tropopause foldings connected with synoptic scale disturbances and through transports along isentropic surfaces [e.g., Holton et al., 1995]. $\mathrm{O}_{3} s$ columns are smaller in the $\mathrm{NH}$ in September/October (Figure 5b) because crosstropopause transports of $\mathrm{O}_{3}$ minimize in the autumn [Roelofs and Lelieveld, 1997]. Between $5^{\circ} \mathrm{S}$ and $15^{\circ} \mathrm{N}$ the contribution of $\mathrm{O}_{3}$ s to total $\mathrm{O}_{3}$ is at minimum $(<5 \mathrm{DU})$ because local down-

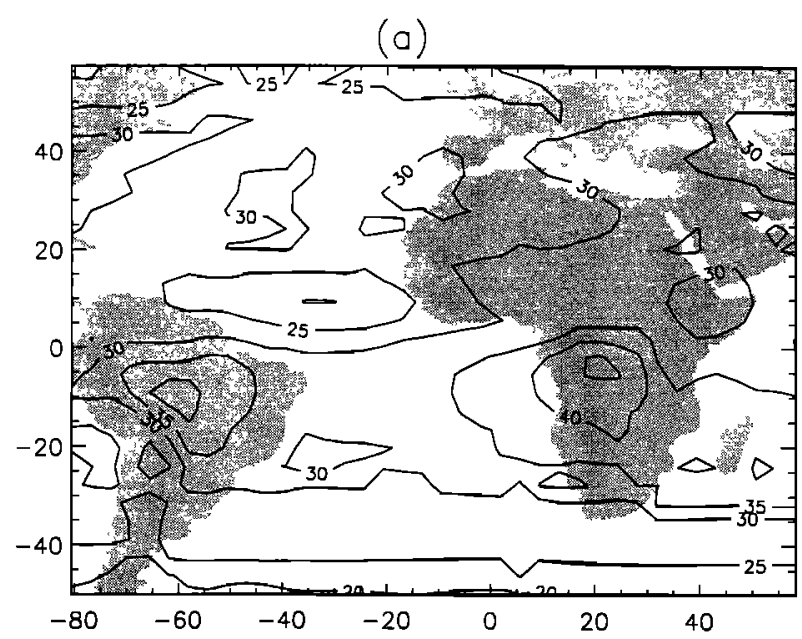

(b)

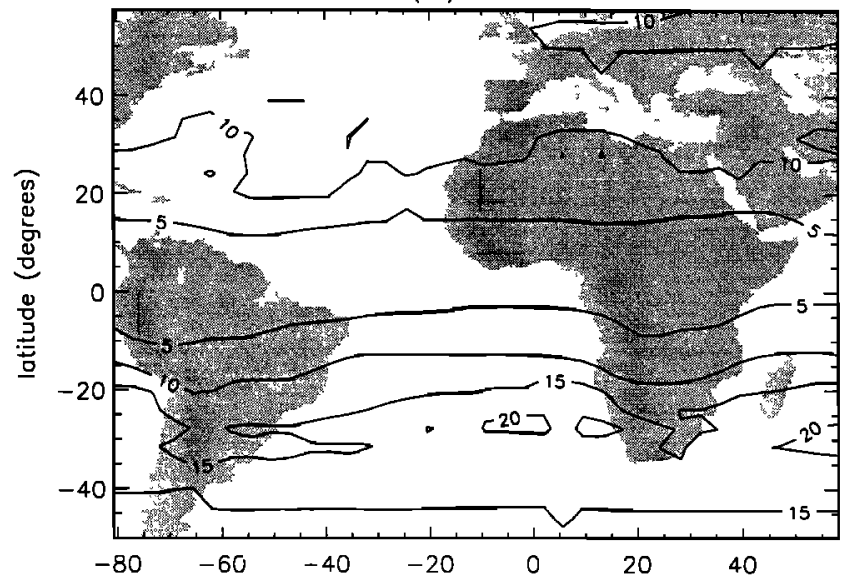

(c)

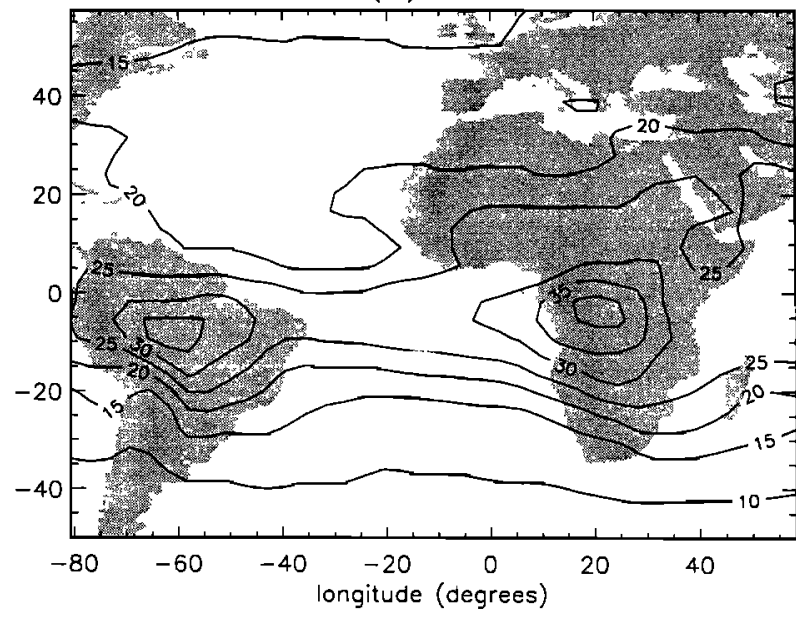

Figure 5. Simulated tropospheric columns (Dobson units (DU)) over the Atlantic Ocean and adjacent continents of (a) total $\mathrm{O}_{3}$, (b) $\mathrm{O}_{3} s$, and (c) $\mathrm{O}_{3} t$, averaged over September/ October. 


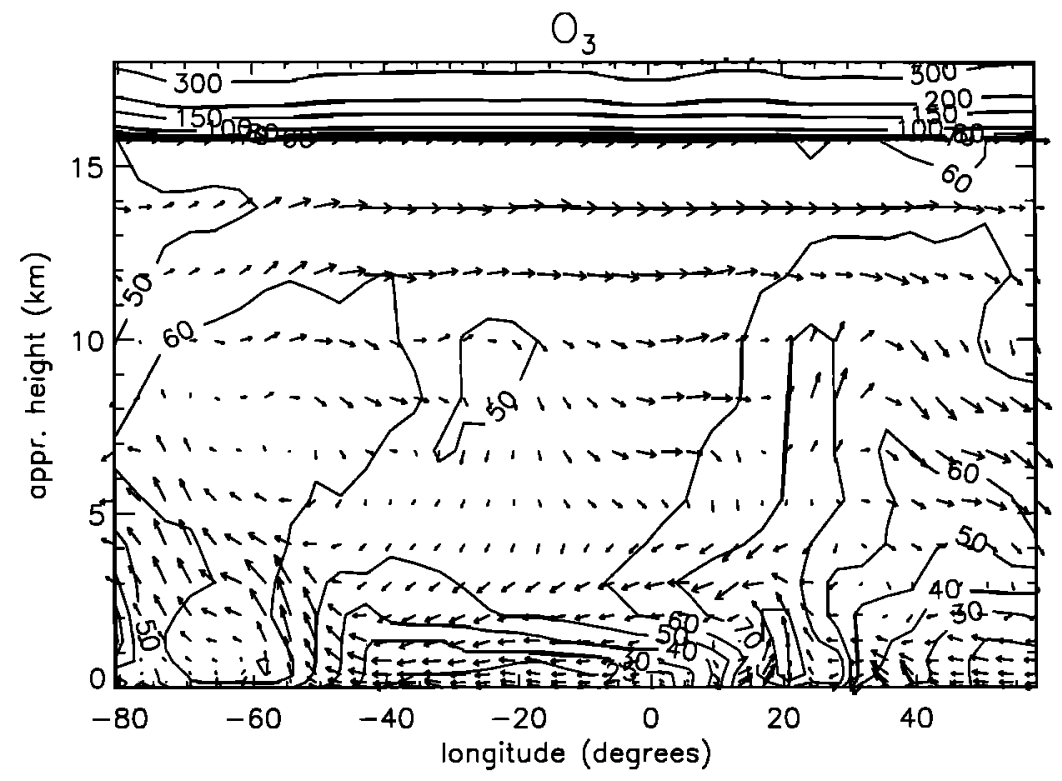

Figure 6. Longitudinal cross section of simulated $\mathrm{O}_{3}$ mixing ratios (ppbv) for the month September at approximately $6^{\circ} \mathrm{S}$. Also shown are the simulated wind fields (arrow length in arbitrary units).

ward transport from the stratosphere is insignificant and photochemical destruction is efficient. In September and October, the dry season, biomass burning is at its maximum in the SH. Large amounts of photochemically produced $\mathrm{O}_{3}$ prevail over the Atlantic Ocean around $5^{\circ} \mathrm{S}$ latitude, an area where biomass burning emissions from South America and Africa converge (Figure 5c). Transport to the Indian Ocean region of $\mathrm{O}_{3}$ from African biomass burning areas also appears to be significant. Southward of $20^{\circ} \mathrm{S}$, total $\mathrm{O}_{3}$ columns decrease as the influence of $\mathrm{O}_{3} t$, the principal $\mathrm{O}_{3}$ component in the tropics, decreases. However, $\mathrm{O}_{3} s$ becomes increasingly important and dominates poleward of $30^{\circ} \mathrm{S}$. Over the ocean at about $10^{\circ} \mathrm{N}, \mathrm{O}_{3}$ columns are relatively low, associated with efficient photochemical destruction in the ITCZ. In middle latitudes in the $\mathrm{NH}$, relatively large amounts of $\mathrm{O}_{3} t$ are found, but longitudinal differences are much smaller compared to the $\mathrm{SH}$.

\subsection{Transports of $\mathrm{O}_{3}$ Over the Tropical South Atlantic Ocean}

In this section we analyze the simulated atmospheric wind fields in the considered region and their impact on the distributions of $\mathrm{O}_{3}$ from the stratosphere and the troposphere. The distributions shown in this section and in section 5 display $\mathrm{O}_{3}$ concentrations and wind vectors that are averaged over the second half of September of the second simulated year. We emphasize that simulated instantaneous wind fields and $\mathrm{O}_{3}$ distributions are characterized by relatively high temporal and spatial variability due to synoptic scale features, as is illustrated in Figure 3. The averaging is applied in order to reduce the day-to-day variability of the calculated wind fields and $\mathrm{O}_{3}$ distributions. The averaged fields illustrate transport and $\mathrm{O}_{3}$ patterns on a timescale which is representative for the large scale transports in the South Atlantic Ocean region. For example, in the latitude band $0^{\circ}-10^{\circ} \mathrm{S}$, lower tropospheric transports from the African $\left(20^{\circ} \mathrm{E}\right)$ to the South American $\left(40^{\circ} \mathrm{W}\right)$ continent take place on a timescale of 5-10 days [e.g., Thompson et al., 1996b, Plate 1].

Figure 6 shows the longitudinal distribution of $\mathrm{O}_{3}$ along $6^{\circ} \mathrm{S}$, the latitude where photochemical $\mathrm{O}_{3}$ columns $\left(\mathrm{O}_{3} t\right)$ maximize (Figure 5c). The stratospheric $\mathrm{O}_{3}$ component is relatively small near the equator; $\mathrm{O}_{3}$ levels are dominated by photochemical formation in the troposphere, mostly due to biomass burning. Therefore the separate $\mathrm{O}_{3} s$ and $\mathrm{O}_{3} t$ distributions are not shown. Vertical winds in Figure 6 represent large scale rising and sinking motions, not the individual convective updrafts and associated downdrafts. Between $15^{\circ}$ and $20^{\circ} \mathrm{E}$, over the African continent, the model simulates an inversion layer at an altitude of about $3 \mathrm{~km}$, where $\mathrm{O}_{3}$ convergence takes place at the top of the boundary layer. Easterly advection transports $\mathrm{O}_{3}$-rich air from Africa over the Atlantic Ocean at about 3-4 $\mathrm{km}$ altitude. Near the west coast of Africa, at about $15^{\circ} \mathrm{E}$, the simulated vertical profile resembles the vertical distribution of $\mathrm{O}_{3}$ measured in Congo during the dry season, which shows relatively high $\mathrm{O}_{3}$ concentrations between 1 and $4 \mathrm{~km}$ altitude [Crutzen and Andreae, 1990].

Between $60^{\circ}$ and $70^{\circ} \mathrm{W}$, over South America, $\mathrm{O}_{3}$ levels are relatively high in the lower troposphere (up to $80 \mathrm{ppbv}$ ). This $\mathrm{O}_{3}$ is advected upward relatively efficiently up to about $12 \mathrm{~km}$ altitude. The $\mathrm{O}_{3}$ precursors $\mathrm{NO}_{x}$ and $\mathrm{CO}$, not shown here, are also transported upward. The model simulates $\mathrm{NO}_{\mathrm{x}}$ levels between about 100 and 500 parts per trillion by volume (pptv) between the boundary layer and $10 \mathrm{~km}$ altitude, as will be discussed in section 5 . These concentrations suffice to cause significant additional photochemical production of $\mathrm{O}_{3}$ in the free troposphere. At high altitudes, westerly wind carries $\mathrm{O}_{3}$ from South America over the ocean toward Africa. Further, air motions between 5 and $10 \mathrm{~km}$ altitude over eastern Africa efficiently transport $\mathrm{O}_{3}$ precursors and photochemically produced $\mathrm{O}_{3}$ eastward, leading to a band of relatively high column $\mathrm{O}_{3}$ between $10^{\circ}$ and $30^{\circ} \mathrm{S}$ over the Indian Ocean [Fishman et al., 1990; Roelofs and Lelieveld, 1997]. The simulated low-level flow from the African continent and eastward transports at higher altitudes from the South American continent resemble the October 1989 meteorology in the region presented by Krishnamurti et al. [1993] and agree well with the trajectory 
analyses of SAFARI/TRACE A [Thompson et al., 1996a]. The simulated marine lower troposphere is characterized by a relatively strong vertical gradient of $\mathrm{O}_{3}$, with mixing ratios up to $70 \mathrm{ppbv}$ at about $3 \mathrm{~km}$ altitude and $25 \mathrm{ppbv}$ at the surface. The latter is associated with southeasterly transports of boundary layer air (of which Figure 6 shows the westward component) from middle latitudes toward the ITCZ, characterized by relatively low $\mathrm{O}_{3}$ levels.

Figure 7 shows latitude-altitude distributions of $\mathrm{O}_{3}, \mathrm{O}_{3} s$, and $\mathrm{O}_{3} t$ over the central Atlantic Ocean along $30^{\circ} \mathrm{W}$. The large scale wind pattern clearly signifies the Hadley circulation and its impact on the $\mathrm{O}_{3}$ distribution. A relatively $\mathrm{O}_{3}$-poor column of air is simulated at $10^{\circ} \mathrm{N}$, where the ITCZ is located. The combination of high insolation and high water vapor concentrations leads to efficient photochemical destruction of $\mathrm{O}_{3}$ near the ocean surface, mainly through photodissociation of $\mathrm{O}_{3}$ and subsequent reaction of $\mathrm{O}\left({ }^{1} D\right)$ with water vapor. Convection at the ITCZ efficiently transports the $\mathrm{O}_{3}$-depleted surface air upward to the middle and upper troposphere. Downward transports of relatively $\mathrm{O}_{3}$-rich air, mostly originating from the stratosphere, occur north and south of the ITCZ between $20^{\circ}$ and $40^{\circ}$ latitude. $\mathrm{O}_{3}$ from photochemical production is abundant between the SH middle latitudes and the equator, largely due to biomass burning emissions, and throughout the $\mathrm{NH}$, largely due to industrial emissions. The SH Hadley circulation includes surface winds toward the ITCZ, which carry $\mathrm{O}_{3}$-poor air, whereas the overlying layer is polluted by $\mathrm{O}_{3}$ from the African biomass burning regions. Mixing between both layers appears to be relatively inefficient, resulting in a strong stratification of $\mathrm{O}_{3}$ levels in the Atlantic lower troposphere. This agrees with the $\mathrm{O}_{3}$ concentration profiles measured at Ascension Island $\left(8^{\circ} \mathrm{S}, 15^{\circ} \mathrm{W}\right)$, which show $\mathrm{O}_{3}$ mixing ratios of about $25 \mathrm{ppbv}$ at the surface up to $70 \mathrm{ppbv}$ at $3 \mathrm{~km}$ altitude [Thompson et al., 1996a]. In the NH lower troposphere the simulated vertical $\mathrm{O}_{3}$ concentration gradient is smaller than in the $\mathrm{SH}$, as is also apparent from observations [Smit et al., 1990; Weller et al., 1996].

Finally, Figures 8 and 9 display horizontal wind fields and $\mathrm{O}_{3}, \mathrm{O}_{3} s$, and $\mathrm{O}_{3} t$ distributions for approximate altitudes of 2.1 $\mathrm{km}(750 \mathrm{hPa})$ and $6.8 \mathrm{~km}(400 \mathrm{hPa})$. At $2.1 \mathrm{~km}$ (Figure 8), easterly flow from the African continent is associated with relatively high $\mathrm{O}_{3}$ mixing ratios. This flow influences $\mathrm{O}_{3}$ levels over Ascension Island and even over South America [cf. Fishman et al., 1991; Logan and Kirchhoff, 1986; Thompson et al., 1996a]. On the other hand, $\mathrm{O}_{3}$-rich air from the South American biomass burning regions is transported to the southeast, under the influence of a subtropical anticyclone. The anticyclone develops near the South American east coast and then traverses the ocean toward Africa approximately along $25^{\circ} \mathrm{S}$. Because Figure 8 displays 2-weekly averaged wind fields, this appears as an extended band between both continents. In the (sub) tropical areas the stratospheric $\mathrm{O}_{3}$ component generally contributes less than $10 \%$ to the calculated $\mathrm{O}_{3}$ levels (Figure $8 \mathrm{~b})$. Consequently, $\mathrm{O}_{3}$ from photochemical production $\left(\mathrm{O}_{3} t\right)$ dominates the (sub) tropical $\mathrm{O}_{3}$ distribution (Figure $8 \mathrm{c}$ ). In the $\mathrm{SH}$ middle latitudes the model calculates surface $\mathrm{O}_{3} s$ mixing ratios above $15 \mathrm{ppbv}$, which contributes about $30-50 \%$ to surface $\mathrm{O}_{3}$ levels. At $6.8 \mathrm{~km}$ altitude (Figure 9), westerlies dominate in the SH. At (sub) tropical latitudes, these winds carry relatively $\mathrm{O}_{3}$-rich air from South America toward Africa. Figure 9c shows that this $\mathrm{O}_{3}$ originates predominantly from photochemical production. However, between $20^{\circ}$ and $40^{\circ} \mathrm{S}$, relatively large $\mathrm{O}_{3} s$ abundances are simulated, indicating relatively

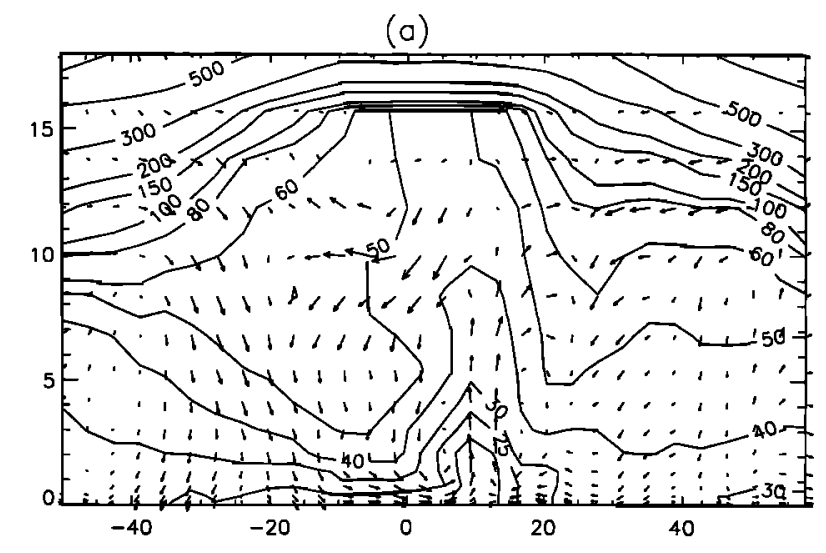

(b)

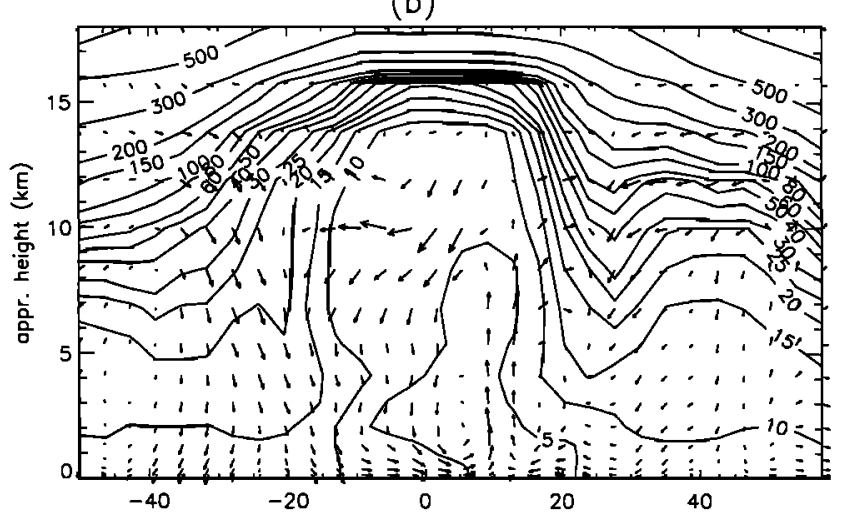

(c)

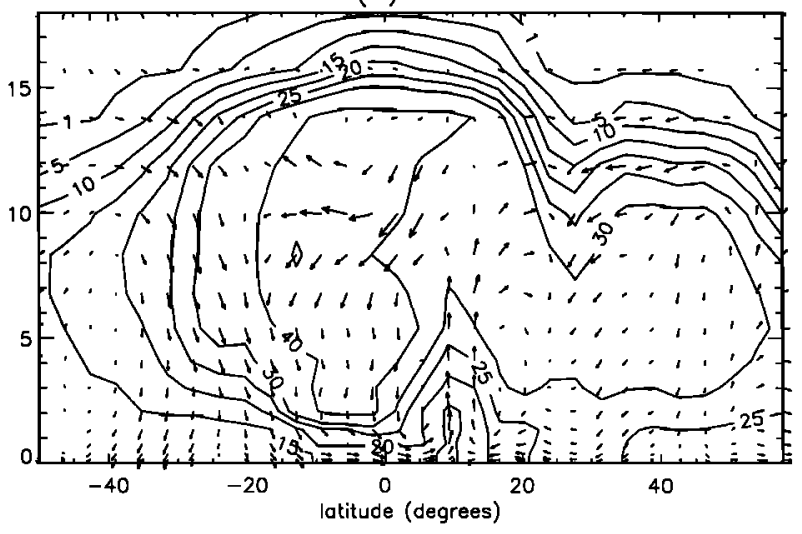

Figure 7. Latitudinal cross section of simulated mixing ratios (ppbv) for (a) total $\mathrm{O}_{3}$, (b) $\mathrm{O}_{3} s$, and (c) $\mathrm{O}_{3} t$ for the month September at approximately $30^{\circ} \mathrm{W}$. Also shown are the simulated wind fields (arrow length in arbitrary units).

efficient STE in this region. Here $\mathrm{O}_{3}$ from the stratosphere contributes significantly to total $\mathrm{O}_{3}$ levels.

\section{Photochemical $\mathbf{O}_{3}$ Production and Destruction}

Figure 10 shows the longitudinal distribution of the calculated net $\mathrm{O}_{3}$ production/destruction rate along $6^{\circ} \mathrm{S}$, coincident with the $\mathrm{O}_{3}$ distribution in Figure 6. The model simulates relatively strong net $\mathrm{O}_{3}$ production over South America and Africa, from about $50 \mathrm{ppbv} \mathrm{d}^{-1}$ near the surface to $4 \mathrm{ppbv} \mathrm{d}^{-1}$ 
(a)

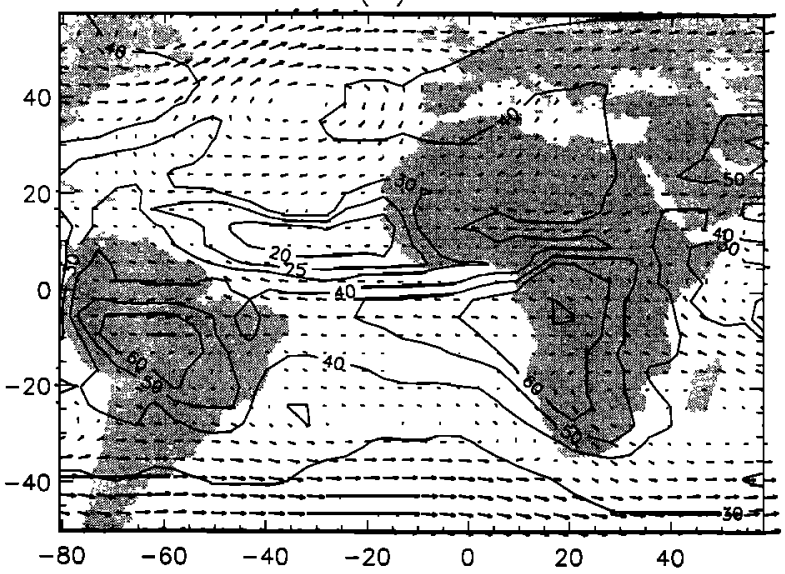

(b)

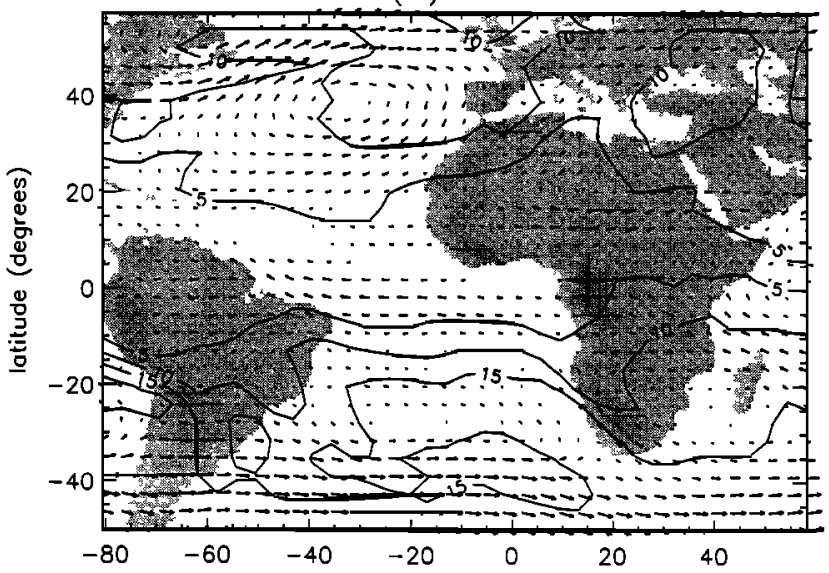

(c)

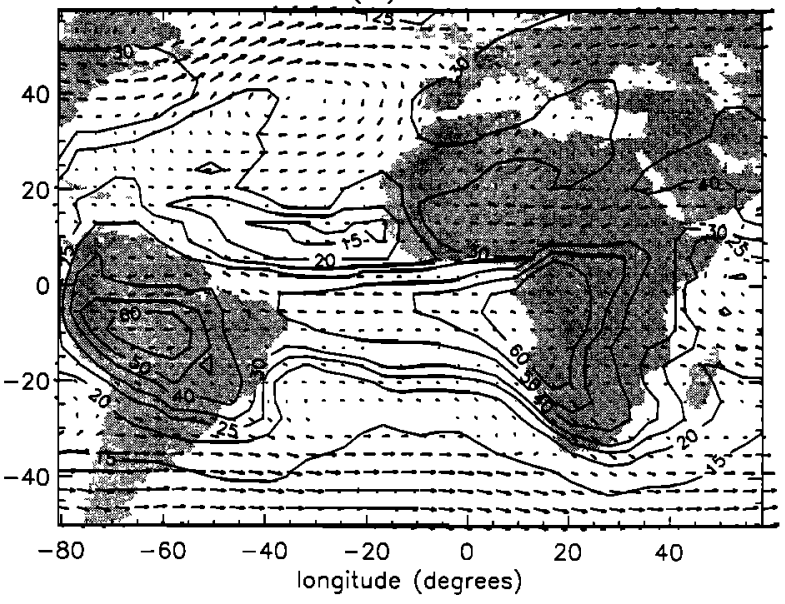

Figure 8. Simulated mixing ratios (ppbv) for (a) total $\mathrm{O}_{3}$, (b) $\mathrm{O}_{3} s$, and (c) $\mathrm{O}_{3} t$ for the month September at an altitude of 2.1 $\mathrm{km}(750 \mathrm{hPa})$. Also shown are the simulated wind fields (arrow length in arbitrary units).

between 8 and $12 \mathrm{~km}$ altitude. The upper tropospheric $\mathrm{O}_{3}$ production rates result from convective activity in the region, which vertically redistributes surface emitted pollutants. Pickering et al. [1996] calculate an $\mathrm{O}_{3}$ production rate up to 7-8 ppbv $d^{-1}$ in convective outflow. Note that this cannot be directly compared to our results because of the subgrid scale representation of convection in the climate model. Lightning emissions of NO may add significantly to $\mathrm{O}_{3}$ production in the free troposphere [e.g., Levy et al., 1996; Pickering et al., 1996]. Destruction of $\mathrm{O}_{3}$ dominates over the Atlantic Ocean in the lower troposphere. Destruction is most efficient near the ocean
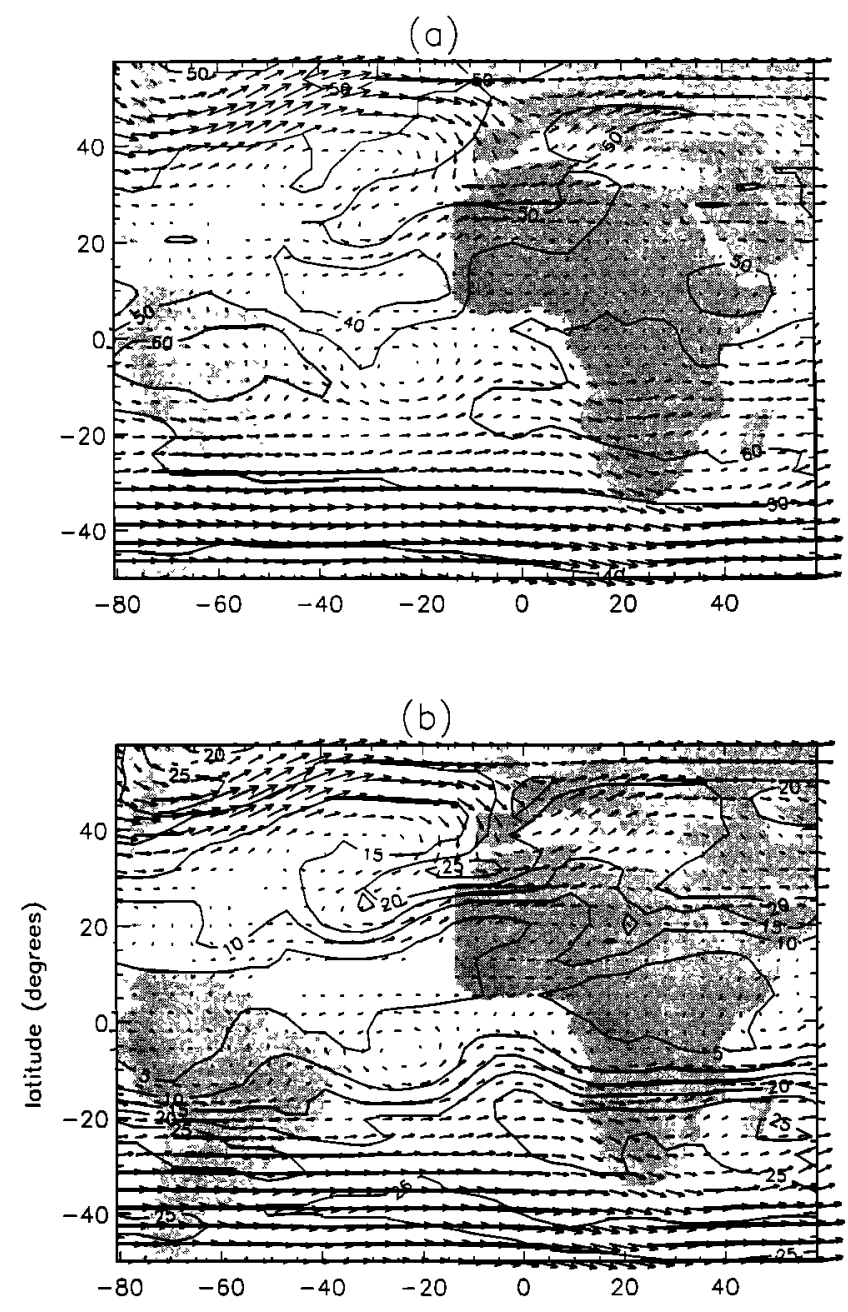

(c)

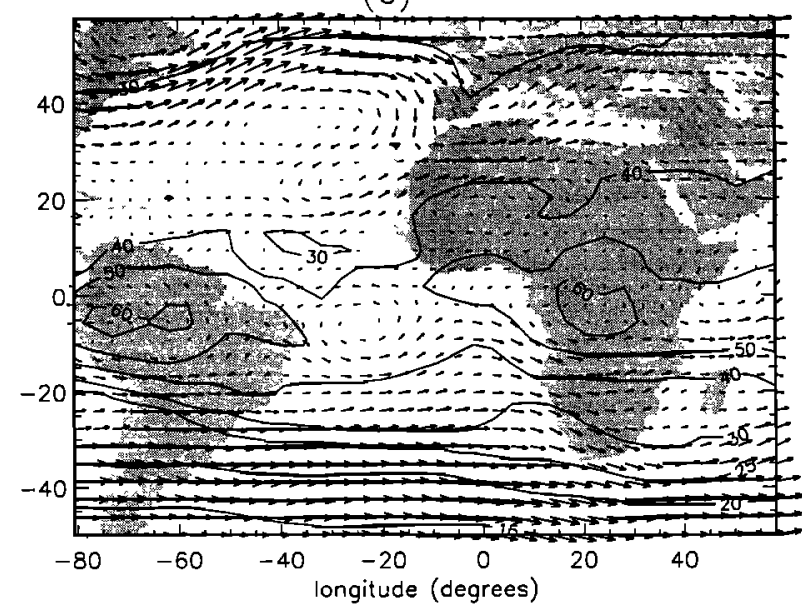

Figure 9. As in Figure 7, but for $6.8 \mathrm{~km}$ altitude $(400 \mathrm{hPa})$. 


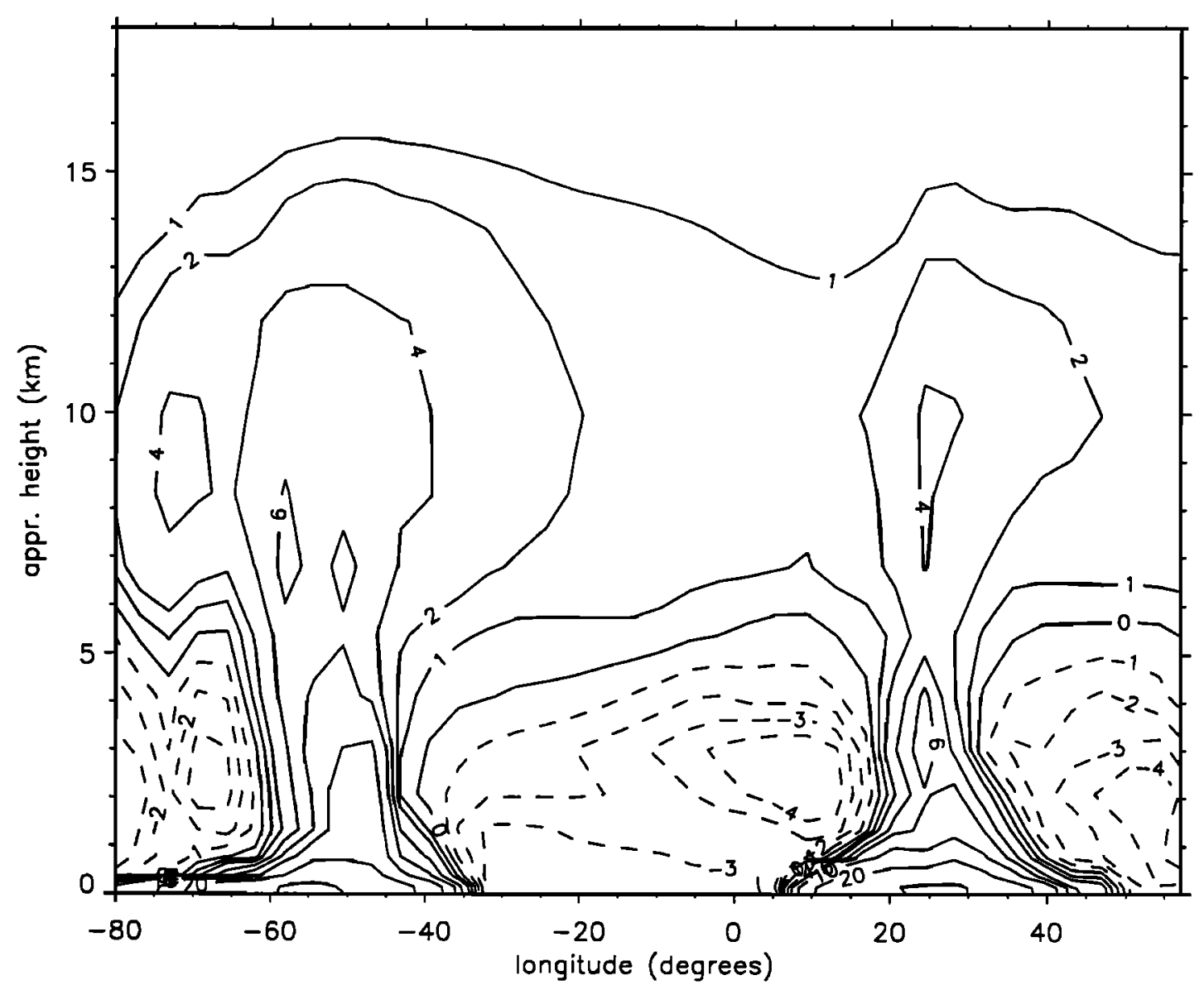

Figure 10. Longitudinal cross section of simulated $\mathrm{O}_{3}$ production/destruction rates (ppbv $\mathrm{d}^{-1}$ ) for the month September at approximately $6^{\circ} \mathrm{S}$. The net photochemical production/destruction rate is the difference between $\mathrm{O}_{3}$ production through reactions of $\mathrm{NO}$ with $\mathrm{HO}_{2}$ and with $\mathrm{CH}_{3} \mathrm{O}_{2}$ (higher hydrocarbon chemistry is neglected in the model) and $\mathrm{O}_{3}$ destruction through reactions of $\mathrm{O}_{3}$ with $\mathrm{OH}$ and with $\mathrm{HO}_{2}$ and of $\mathrm{O}\left({ }^{1} D\right)$ with water vapor, averaged over 2 weeks.

surface, where water vapor concentrations are high. In addition, at $10^{\circ} \mathrm{E}$, at about $2.5 \mathrm{~km}$ altitude, $\mathrm{O}_{3}$ levels are high (Figure 6), and $\mathrm{NO}_{\mathrm{x}}$ is rapidly depleted during transport, giving rise to a local $\mathrm{O}_{3}$ destruction maximum. Figure 11 shows latitudinal distributions of the $\mathrm{O}_{3}$ precursors $\mathrm{NO}_{x}$ and $\mathrm{CO}$. It can be seen that $\mathrm{NO}_{\mathrm{x}}$ mixing ratios decrease from more than 200 pptv over Africa to $10-100$ pptv over the ocean. The model simulates rapid conversion from $\mathrm{NO}_{x}$ to $\mathrm{HNO}_{3}$ in the African outflow region, where $\mathrm{HNO}_{3}$ mixing ratios up to 2000 pptv are calculated. Although measurements during TRACE A indicate lower $\mathrm{HNO}_{3}$ levels, between 150-1000 pptv, peroxyacetylnitrate (PAN) ranges between 10 and $1500 \mathrm{pptv}$, so that measured $\mathrm{NO}_{\mathrm{y}}$ concentrations are between 200 and $2100 \mathrm{pptv}$ [Talbot et al., 1996]. This is comparable to the $\mathrm{NO}_{\mathrm{y}}$ simulated in the outflow region, to which $\mathrm{HNO}_{3}$ contributes over $95 \%$ (note that PAN is neglected in our model). In the outflow region, CO levels decrease from over 500 ppbv over the continent to about $150 \mathrm{ppbv}$ at $40^{\circ} \mathrm{W}$. Although we do not discuss simulated $\mathrm{NO}_{\mathrm{x}}$ and $\mathrm{CO}$ distributions in detail, we emphasize that the distributions displayed in Figure 11 agree relatively well with data presented by Jacob et al. [1996, Plate 2], Talbot et al. [1996], and Connors and Reichle [1996]. Hence $\mathrm{NO}_{\mathrm{x}}$ concentrations decrease strongly during transport from the sources, so that steep gradients between $\mathrm{O}_{3}$ production and destruction regions develop. Similar gradients occur over the
South American west coast and the African east coast, whereas they diminish at altitudes above $5 \mathrm{~km}$. Here air originating from South American biomass burning areas is transported eastward (Figures 6 and 9). $\mathrm{O}_{3}$ production and loss rates, which have been derived from TRACE A measurements, follow similar patterns. For the South Atlantic basin, Thompson et al. [1996a] calculated a net $\mathrm{O}_{3}$ production/loss between -2.6 and $-6 \mathrm{ppbv} \mathrm{d}^{-1}$ at $0-4 \mathrm{~km}$, between -0.6 and $+1.6 \mathrm{ppbv} \mathrm{d}^{-1}$ at $4-8 \mathrm{~km}$, and between 1.5 and $2.6 \mathrm{ppbv} \mathrm{d}^{-1}$ at $8-12 \mathrm{~km}$. For the same layers, Jacob et al. [1996, Plate 1b] calculated about -1 to $-5,0$ to 3 , and higher than 2 ppbv $d^{-1}$, respectively. It should be noted that TRACE A measurements were carried out mostly between $10^{\circ}$ and $20^{\circ} \mathrm{S}$. The simulated vertical distribution of $\mathrm{O}_{3}$ production/destruction is similar at these latitudes, but the net production/destruction rates are somewhat lower than at $6^{\circ} \mathrm{S}$. The simulated values are therefore rather low compared to the TRACE A analyses. However, the calculated rates are averaged over 2 weeks. Instantaneous noontime production/destruction rates simulated by the model are 100 to $200 \mathrm{ppbv} \mathrm{d}^{-1}$ in the continental surface layer, -4 to $-8 \mathrm{ppbv}$ $d^{-1}$ in the outflow regions and near the ocean surface, and they exceed 4 ppbv $\mathrm{d}^{-1}$ in the upper troposphere over the ocean.

Figure 12 shows calculated $\mathrm{O}_{3}$ production/destruction rates, integrated over the troposphere. Net $\mathrm{O}_{3}$ production is limited to the continents, where it exceeds $6 \mathrm{DU} \mathrm{d}^{-1}$. Net destruction 

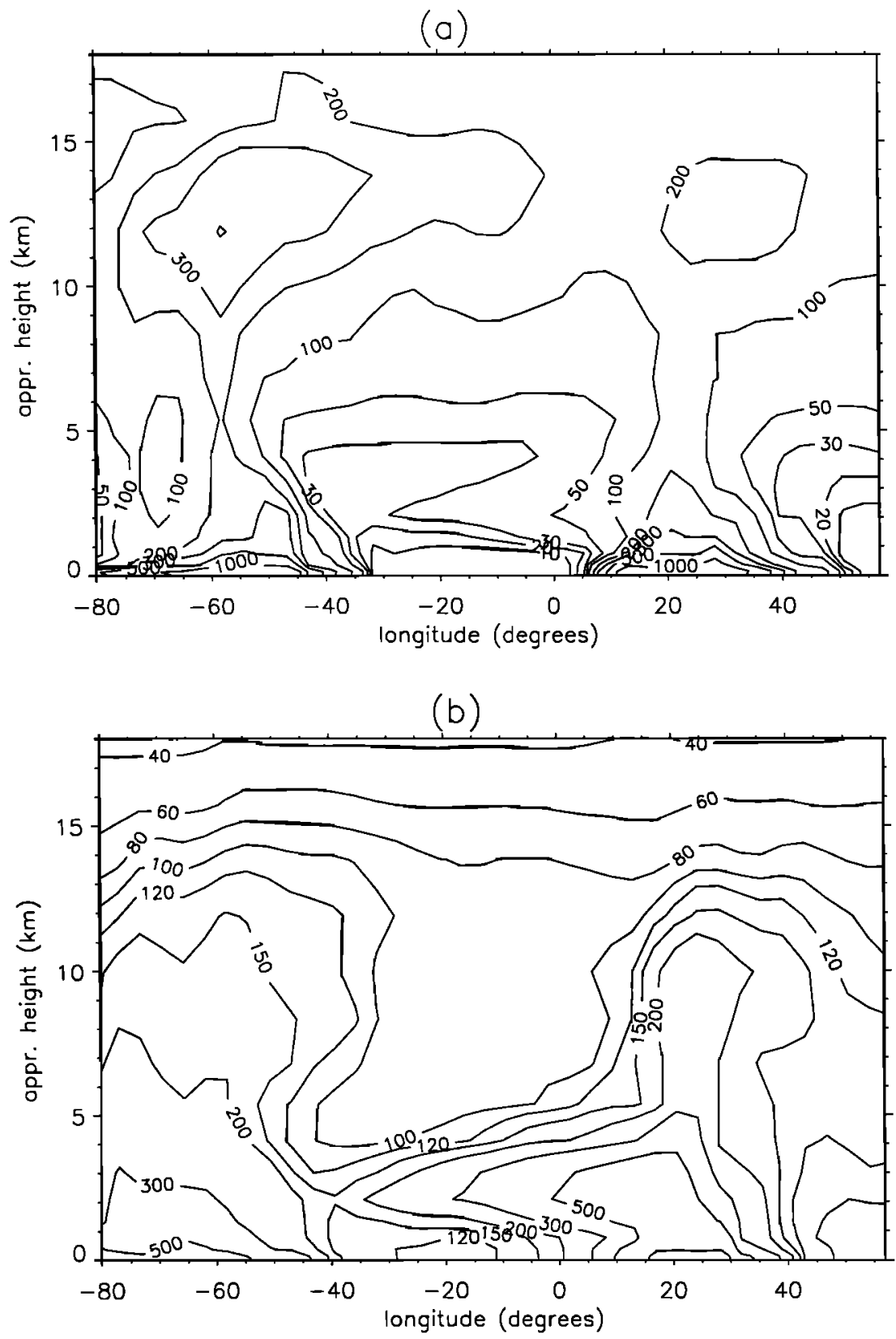

Figure 11. Longitudinal cross section of simulated (a) $\mathrm{NO}_{\mathrm{x}}$ (parts per trillion by volume (pptv)) and (b) $\mathrm{CO}$ (ppbv) for the month September at approximately $6^{\circ} \mathrm{S}$.

prevails over the oceans. At the ITCZ, between $10^{\circ}$ and $20^{\circ} \mathrm{N}$, net $\mathrm{O}_{3}$ loss rates of $0.5-1.0 \mathrm{DU} \mathrm{d}^{-1}$ are calculated, corresponding with a relative $\mathrm{O}_{3}$ column decrease of $3-4 \% \mathrm{~d}^{-1}$ (cf. Figure 5). In the South Atlantic Ocean the model simulates efficient $\mathrm{O}_{3}$ destruction near the central African west coast, coinciding with the African outflow region (approximately $1 \mathrm{DU} \mathrm{d}^{-1} ; 2 \%$ $\mathrm{d}^{-1}$ ), and near $20^{\circ} \mathrm{S}$ latitude, where lower tropospheric air originating from South American biomass burning areas is transported eastward (Figure 8) (0.3-0.5 DU d $\mathrm{d}^{-1} ; 1-2 \% \mathrm{~d}^{-1}$ ). Total tropospheric column-integrated $\mathrm{O}_{3}$ production/loss rates are dominated by the chemistry in the lowest $4 \mathrm{~km}$. For the column between 4 and $12 \mathrm{~km}$ the model simulates a net production up to $0.5 \mathrm{DU} \mathrm{d}^{-1}$ over the (sub) tropical Atlantic Ocean and up to $1 \mathrm{DU} \mathrm{d}^{-1}$ over the continents. Modeled distributions of the column production/destruction rates over the ocean agree reasonably well with $\mathrm{O}_{3}$ destruction rates derived from TRACE A measurements, which range between -1.3 and $-0.2 \mathrm{DU} \mathrm{d}^{-1}$ [Thompson et al., 1996a]. However, in contrast with the model results, two TRACE A flights indicated a net $\mathrm{O}_{3}$ production of about $0.5 \mathrm{DU} \mathrm{d}^{-1}$ over the ocean near the west coast of central Africa. Further, TOMS $\mathrm{O}_{3}$ data suggest a net production of $0.85-2.2 \mathrm{DU} \mathrm{d}^{-1}$ during transport from Brazzaville to Ascencion [Thompson et al., 1996b], which is directly over the African outflow region.

\section{Conclusions}

We have applied our chemistry-climate model to analyze the influence of transports on the $\mathrm{O}_{3}$ distribution over the $\mathrm{SH}$ (sub) tropical Atlantic Ocean. In this region, photochemically 


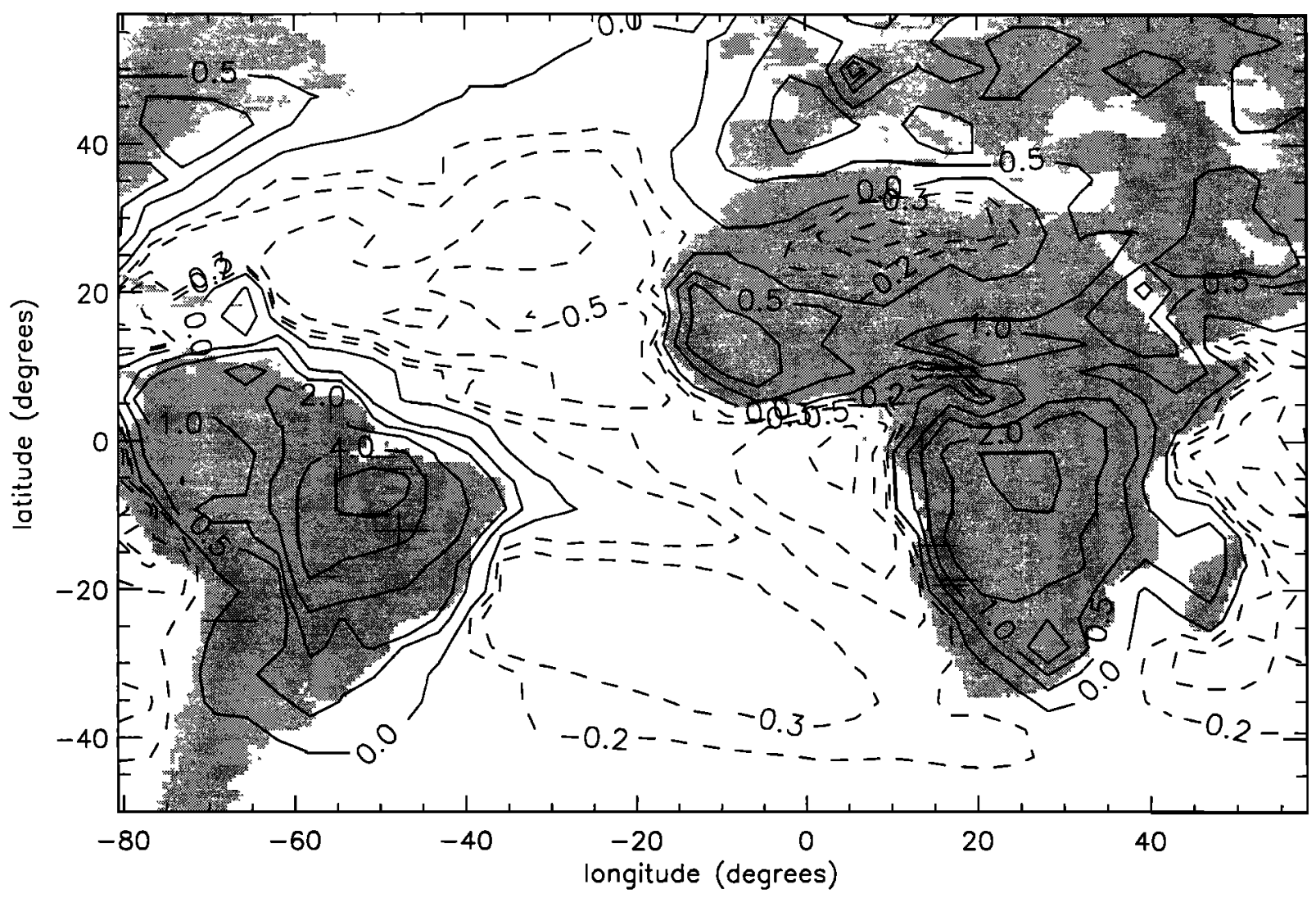

Figure 12. Simulated column-integrated $\mathrm{O}_{3}$ production/destruction rate $\left(\mathrm{DU} \mathrm{d}^{-1}\right)$ for the month September.

produced $\mathrm{O}_{3}$ is largely associated with biomass burning emissions which maximize in September/October, the dry season in the $\mathrm{SH}$. The model results show that in the boundary layer, relatively unpolluted marine air is transported from the southeast. Above the boundary layer, between approximately 2 and $5 \mathrm{~km}$ altitude, relatively $\mathrm{O}_{3}$-rich air is transported into the region from the east where the African biomass burning regions are located. Above $5 \mathrm{~km}, \mathrm{O}_{3}$ levels are influenced by westerlies which advect air from the South American biomass burning regions. The model simulates average $\mathrm{O}_{3}$ production rates of $10-50 \mathrm{ppbv} \mathrm{O}_{3} \mathrm{~d}^{-1}$ in the lower troposphere over the biomass burning regions and lower production rates, up to 3 ppbv $\mathrm{O}_{3} \mathrm{~d}^{-1}$, in the middle and upper troposphere. Photochemical destruction of $\mathrm{O}_{3}$ prevails over the ocean in the lower troposphere, maximizing in the African and South American outflow regions. Between $0^{\circ}$ and $20^{\circ} \mathrm{S}$, tropospheric $\mathrm{O}_{3}$ levels are dominated by photochemically produced $\mathrm{O}_{3}$, while transport of $\mathrm{O}_{3}$ from the stratosphere is of minor importance. However, between $20^{\circ}$ and $30^{\circ} \mathrm{S}$, about $50 \%$ of the $\mathrm{O}_{3}$ column is determined by transport from the stratosphere, and the stratospheric $\mathrm{O}_{3}$ source dominates at higher latitudes. Simulated wind fields in the region agree well with ECMWF analyses presented by Krishnamurti et al. [1993]. Further, the strong vertical wind shear in SH tropical latitudes, leading to $180^{\circ}$ different wind directions as also shown by Thompson et al. [1996a], is reproduced well by the model.

We have compared modeled $\mathrm{O}_{3}$ distributions over the Atlantic Ocean with a latitudinal and vertical $\mathrm{O}_{3}$ distribution measured in September/October 1988 [Smit et al., 1990]. The measurements and calculations show a column of relatively $\mathrm{O}_{3}$-low air near $10^{\circ} \mathrm{N}$, associated with the convective ITCZ, where photochemical destruction predominates. They also show regions with much higher $\mathrm{O}_{3}$ mixing ratios north and south of the ITCZ. Model results indicate that these are due to downward transports of $\mathrm{O}_{3}$ from the stratosphere and to photochemical $\mathrm{O}_{3}$ formation in the troposphere. The measured and modeled $\mathrm{O}_{3}$ distributions agree reasonably well in the upper and middle troposphere, whereas the modeled $\mathrm{O}_{3}$ variability is of the same order as the measured variability.

However, absolute $\mathrm{O}_{3}$ levels over the $\mathrm{SH}$ tropical Atlantic Ocean appear to be generally underestimated by the model. Notably, a discrepancy is found in the lower troposphere between about $20^{\circ}$ and $0^{\circ} \mathrm{S}$, where mixing ratios measured by Smit et al. [1990] are up to a factor of 2 higher than the model results. Further, simulated free tropospheric $\mathrm{O}_{3}$ mixing ratios over Ascension Island are significantly lower than measured [Thompson et al., 1996a]. Note, however, that the free tropospheric $\mathrm{O}_{3}$ levels measured on board the Polarstern at the same latitude are also somewhat lower, about $10-20$ ppbv. Further, $\mathrm{O}_{3}$ abundances measured during TRACE A, which are associated with South American biomass burning emissions, appear rather high compared to climatological values [Fishman et al., 1996b]. Nevertheless, tropospheric $\mathrm{O}_{3}$ columns over the $\mathrm{SH}$ Atlantic Ocean from the TOMS/SAGE climatology are up to 10 DU higher than calculated columns [Fishman et al., 1990; Hudson et al., 1995]. This discrepancy may be partly due to the tropopause height definition, which is a critical parameter in tropospheric $\mathrm{O}_{3}$ column calculations as well as satellite data retrieval. Nevertheless, it is likely that the model underestimates photochemical production of $\mathrm{O}_{3}$ in the area because higher hydrocarbons released by biomass burning have not been considered. First, higher hydrocarbon emissions may lead 
to a more efficient in situ production of $\mathrm{O}_{3}$ near the source regions. Model results indicate that over the source regions, in the lower troposphere, strong $\mathrm{O}_{3}$ production occurs. Second, some of these hydrocarbons and reservoir species such as PAN have lifetimes of a few days to weeks and may lead to additional $\mathrm{O}_{3}$ production during transport in the lower- and higheraltitude flows over the Atlantic Ocean. This is corroborated by the fact that our model simulates net $\mathrm{O}_{3}$ destruction over the South Atlantic Ocean, whereas a net $\mathrm{O}_{3}$ production of 1-2 DU $\mathrm{d}^{-1}$ has been derived from TRACE A measurements.

Acknowledgments. This research is part of the SINDICATE project, which is supported by the European Commission (DG XII), and of the joint research with the Center for Clouds, Chemistry, and Climate $\left(\mathrm{C}^{4}\right)$ at the University of California, San Diego ( $\mathrm{C}^{4}$ paper 173). We thank the Max-Planck-Institute for Meteorology in Hamburg for the use of computer facilities and support.

\section{References}

Benkovitz, C. M., M. T. Scholtz, J. Pacyna, L. Tarrason, J. Dignon, E. C. Voldner, P. A. Spiro, J. A. Logan, and T. E. Graedel, Global gridded inventories of anthropogenic emissions of sulfur and nitrogen, J. Geophys. Res., 101, 29,239-29,253, 1996.

Brost, R. A., J. Feichter, and M. Heimann, Three-dimensional simulation of ${ }^{7} \mathrm{Be}$ in a global climate model, J. Geophys. Res., 96, 22,423$22,445,1991$.

Chen, C. T., and E. Roeckner, Validation of the Earth radiation budget as simulated by the Max Planck Institute for Meteorology general circulation model ECHAM4 using satellite observations of the Earth Radiation Budget Experiment, J. Geophys. Res., 101, 4269-4287, 1996.

Connors, V. S., and H. G. Reichle, Space shuttle views changing carbon monoxide in lower atmosphere, Eos, 77, 466-467, 1996.

Crutzen, P. J., Ozone in the troposphere, in Composition, Chemistry, and Climate of the Atmosphere, edited by H. B. Singh, pp. 349-393, Van Nostrand Reinhold, New York, 1995.

Crutzen, P. J., and M. O. Andreae, Biomass burning in the tropics: Impact on atmospheric chemistry and biogeochemical cycles, Science, 250, 1669-1678, 1990 .

Diab, R. D., et al., Vertical ozone distribution over southern Africa and adjacent oceans during SAFARI-92, J. Geophys. Res., 101, 23,823-23,833, 1996.

Feichter, J., R. A. Brost, and M. Heimann, Three-dimensional modeling of the concentration and deposition of ${ }^{210} \mathrm{~Pb}$ aerosols, $J$. Geophys. Res., 96, 22,447-22,460, 1991.

Feichter, J., E. Kjellstrom, H. Rodhe, F. Dentener, J. Lelieveld, and G. J. Roelofs, Simulation of the tropospheric sulfur cycle in a global climate model, Atmos. Environ., 30, 1693-1707, 1996.

Fishman, J., C. E. Watson, J. C. Larsen, and J. A. Logan, Distribution of tropospheric ozone determined from satellite data, J. Geophys. Res., 95, 3599-3617, 1990.

Fishman, J., K. Fakhruzzaman, B. Cros, and D. Nganga, Identification of widespread pollution in the southern hemisphere deduced from satellite analyses, Science, 252, 1693-1696, 1991.

Fishman, J., J. M. Hoell Jr., R. D. Bendura, R. J. McNeal, V. W. J. H. Kirchhof, NASA GTE TRACE A Experiment (September-October 1992): Overview, J. Geophys. Res., 101, 23,865-23,879, 1996a.

Fishman, J., V. G. Brackett, E. V. Browell, and W. B. Grant, Tropospheric ozone derived from TOMS/SBUV measurements during TRACE A, J. Geophys. Res., 101, 24,069-24,082, 1996b.

Ganzeveld, L. N., and J. Lelieveld, Dry deposition parameterization in a chemistry-general circulation model and its influence on the distribution of chemically reactive trace gases, J. Geophys. Res., 100, 20,999-21,012, 1995.

Hao, W. M., and M. H. Liu, Spatial and temporal distribution of tropical biomass burning, Global Biogeochem. Cycles, 8, 495-503, 1994.

Haskins, R. D., T. P. Barnett, M. M. Tyree, and E. Roeckner, Comparison of cloud fields from atmospheric general circulation model, in situ, and satellite measurements, J. Geophys. Res., 100, 1367-1378, 1995.

Hoerling, M. P., T. K. Schaack, and A. J. Lenzen, A global analysis of stratospheric-tropospheric exchange during northern winter, Mon. Weather Rev., 121, 162-172, 1993.

Holton, J. R., P. H. Haynes, M. E. McIntyre, A. R. Douglas, R. B. Rood, and L. Pfister, Stratosphere-troposphere exchange, Rev. Geophys., 33, 403-439, 1995.

Hudson, R. D., J. H. Kim, and A. M. Thompson, On the derivation of tropospheric column ozone from radiances measured by the total ozone mapping spectrometer, J. Geophys. Res., 100, 11,137-11,145, 1995.

Intergovernmental Panel on Climate Change (IPCC), Climate Change, edited by J. T. Houghton, L. G. Meira Filho, J. Bruce, H. Lee, B. A. Callander, E. Haites, N. Harris, and K. Maskell, Cambridge Univ. Press, New York, 1994.

Jacob, D. J., et al., Origin of ozone and $\mathrm{NO}_{\mathrm{x}}$ in the tropical troposphere: A photochemical analysis of aircraft observations over the South Atlantic basin, J. Geophys. Res., 101, 24,235-24,250, 1996.

Jeuken, A. B. M., P. C. Siegmund, L. C. Heijboer, J. Feichter, and L. Bengtsson, On the potential of assimilating meteorological analyses in a global climate model for the purpose of model validation, $J$. Geophys. Res., 101, 16,939-16,950, 1996.

Kim, J. H., R. D. Hudson, and A. M. Thompson, A new method of deriving time-averaged tropospheric column ozone over the tropics using total ozone mapping spectrometer (TOMS) radiances: Intercomparison and analysis using TRACE A data, J. Geophys. Res., 101, 24,317-24,330, 1996.

Kirchhoff, V. W. J. H., J. R. Alves, and F. R. da Silva, Observations of ozone concentrations in the Brazilian cerrado during the TRACE A field expedition, J. Geophys. Res., 101, 24,029-24,042, 1996.

Komhyr, W. D., S. J. Oltmans, P. R. Franchois, W. F. J. Evans, and W. A. Matthews, The latitudinal distribution of ozone to $35 \mathrm{~km}$ altitude from ECC ozonesonde observations, 1985-1987, in Ozone in the Atmosphere, edited by R. D. Bojkov and P. Fabian, pp. 147-150, A. Deepak, Hampton, Va., 1989.

Koppmann, R., R. Bauer, F. J. Johnen, C. Plass, and J. Rudolph, The distribution of light nonmethane hydrocarbons over the MidAtlantic: Results of the Polarstern Cruise ANT VII/1, J. Atmos. Chem., 15, 215-234, 1992.

Krishnamurti, T. N., H. E. Fuelberg, M. C. Sinha, D. Oosterhof, E. L. Bensman, and V. B. Kumar, The meteorological environment of the tropospheric ozone maximum over the tropical South Atlantic Ocean, J. Geophys. Res., 98, 10,621-10,641, 1993.

Krishnamurti, T. N., M. C. Sinha, M. Kanamitsu, D. Oosterhof, H. Fuelberg, R. Chatfield, D. J. Jacob, and J. Logan, Passive tracer transport relevant to the TRACE A experiment, J. Geophys. Res., $101,23,889-23,907,1996$.

Lelieveld, J., and P. J. Crutzen, Influences of cloud photochemical processes on tropospheric ozone, Nature, 343, 227-233, 1990.

Lelieveld, J., and R. van Dorland, Ozone chemistry changes in the troposphere and consequent radiative forcing of climate, in Atmospheric Ozone as a Climate Gas, edited by W. C. Wang and I. S. A. Isaksen, pp. 227-258, Springer-Verlag, New York, 1995.

Levy, H., II, W. J. Moxim, and P. S. Kasibhatla, A global threedimensional time dependent lightning source of $\mathrm{NO}_{\mathrm{x}}, J$. Geophys. Res., 101, 22,911-22,922, 1996.

Lindesay, J. A., M. O. Andreae, J. G. Goldammer, G. Harris, H. J. Annegarn, M. Garstang, R. J. Scholes, and B. W. van Wilgen, International Geosphere-Biosphere Programme/International Global Atmospheric Chemistry SAFARI-92 field experiment: Background and overview, J. Geophys. Res., 101, 23,521-23,530, 1996.

Logan, J. A., Trends in the vertical distribution of ozone: An analysis of ozonesonde data, J. Geophys. Res., 99, 25,553-25,585, 1994.

Logan, J. A., and V. W. J. H. Kirchhoff, Seasonal variations of tropospheric ozone at Natal, Brazil, J. Geophys. Res., 91, 7875-7882, 1986.

Lowe, D. C., C. A. Brenninkmeijer, G. W. Brailsford, K. R. Lassey, A. J. Gomez, and E. G. Nisbet, Concentration and ${ }^{13} \mathrm{C}$ records of atmospheric methane in New Zealand and Antarctica: Evidence for changes in methane sources, J. Geophys. Res., 99, 16,913-16,925, 1994

Oltmans, S. J., and H. Levy II, Surface ozone measurements from a global network, Atmos. Environ., 28, 9-24, 1994.

Papenbrock, T., F. Stuhl, K. P. Müller, and J. Rudolph, Measurement of gaseous $\mathrm{HNO}_{3}$ over the Atlantic Ocean, J. Atmos. Chem., 15, $369-379,1992$.

Pickering, K. E., et al., Convective transport of biomass burning emissions over Brazil during Trace A, J. Geophys. Res., 101, 23,993$24,012,1996$. 
Price, C., and D. Rind, A simple lightning parameterization for calculating global lightning distributions, J. Geophys. Res., 97, 9919-9933, 1992.

Rasch, P. J., and D. Williamson, Computational aspects of moisture transport in global models of the atmosphere, Q.J. R. Meteorol. Soc., 116, 1071-1090, 1990.

Roeckner, E., T. Siebert, and J. Feichter, Climatic response to anthropogenic sulfate forcing simulated with a general circulation model, in Aerosol Forcing of Climate, edited by R. J. Charlson and J. Heintzenberg, pp. 349-362, John Wiley, New York, 1995.

Roeckner, E., K. Arpe, L. Bengtsson, M. Christoph, M. Claussen, L. Dümenil, M. Esch, M. Giorgetta, U. Schlese, and U. Schulzweida, The atmospheric general circulation model ECHAM-4: Model description and simulation of present-day climate, Rep. 218, MaxPlanck-Inst. for Meteorol., Hamburg, Germany, 1996.

Roelofs, G. J., and J. Lelieveld, Distribution and budget of $\mathrm{O}_{3}$ in the troposphere calculated with a chemistry-general circulation model, J. Geophys. Res., 100, 20,983-20,998, 1995.

Roelofs, G. J., and J. Lelieveld, Model study of the influence of crosstropopause $\mathrm{O}_{3}$ transports on tropospheric $\mathrm{O}_{3}$ levels, Tellus, Ser. B, 49, 38-55, 1997.

Smit, H. G. J., D. Kley, S. McKeen, A. Volz, and S. Gilge, The latitudinal and vertical distribution of tropospheric ozone over the Atlantic Ocean in the southern and northern hemispheres, in Ozone in the Atmosphere, edited by R. D. Bojkov and P. Fabian, pp. 419422, A. Deepak, Hampton, Va., 1989.

Smit, H. G. J., S. Gilge, and D. Kley, The meridional distribution of ozone and water vapor over the Atlantic Ocean between $30^{\circ} \mathrm{S}$ and $52^{\circ} \mathrm{N}$ in September/October 1988, in Physico-Chemical Behaviour of Atmospheric Pollutants, edited by G. Restelli and G. Angeletti, pp. 630-637, Kluwer Acad., Norwell, Mass., 1990.

Smit, H. G. J., S. Gilge, and D. Kley, Ozone profiles over the Atlantic Ocean between $36^{\circ} \mathrm{S}$ and $52^{\circ} \mathrm{N}$ in March/April 1987 and September/ October 1988, Jul Ber. 2567, Forsch. Julich, West Germany, 1991.

Smit, H. G. J., W. Straeter, and D. Kley, The evaluation of ECCsondes under quasi flight conditions in the environmental simulation chamber at Juelich, paper presented at EUROTRAC Symposium
94, EUROTRAC, Garmisch-Partenkirchen, Bavaria, Germany, 1994.

Talbot, R. W., et al., Chemical characteristics of continental outflow over the tropical South Atlantic Ocean from Brasil and Africa, $J$. Geophys. Res., 101, 24,187-24,202, 1996.

Thompson, A. M., K. E. Pickering, D. P. McNamara, M. R. Schoeberl, R. D. Hudson, J. H. Kim, E. V. Browell, J. Fishman, V. W. J. H. Kirchhoff, and D. Nganga, Where did tropospheric ozone over southern Africa and the tropical Atlantic come from in October 1992? Insights from TOMS, GTE/TRACE-A, and SAFARI-92, $J$. Geophys. Res., 101, 24,251-24,278, 1996a.

Thompson, A. M., et al., Ozone over southern Africa during SAFARI92/TRACE A, J. Geophys. Res., 101, 23,793-23,807, $1996 \mathrm{~b}$.

Tiedtke, M., A comprehensive mass flux scheme for cumulus parameterization in large-scale models, Mon. Weather Rev., 117, 1779$1800,1989$.

Weller, R., R. Lilisschkis, O. Schrems, R. Neuber, and S. Wessel, Vertical ozone distribution in the marine atmosphere over the central Atlantic Ocean $\left(56^{\circ} \mathrm{S}-50^{\circ} \mathrm{N}\right), J$. Geophys. Res., 101, 1387-1399, 1996.

Winkler, P., Surface ozone over the Atlantic Ocean, J. Atmos. Chem., 7, 73-91, 1988.

World Meteorological Organization (WMO), Scientific assessment of depletion: 1994, Global ozone research and monitoring project, Rep. 37, Geneva, Switzerland, 1995.

Yienger, J. J., and H. Levy II, Empirical model of global soil-biogenic $\mathrm{NO}_{\mathrm{x}}$ emissions, J. Geophys. Res., 100, 11,447-11,464, 1995.

D. Kley and H. G. J. Smit, Institute for Chemistry of the Polluted Atmosphere (ICG-2), P.O. Box 1913, D-52425 Jülich, Germany. (e-mail: d.kley@kfa-uelich.de; h.smit@kfa-juelich.de)

J. Lelieveld and G.-J. Roelofs, Institute for Marine and Atmospheric Research Utrecht (IMAU), Princetonplein 5, 3584 CC Utrecht, The Netherlands. (e-mail: lelieveld@fys.ruu.nl; roelofs@fys.ruu.nl)

(Received September 27, 1996; revised February 4, 1997; accepted February 4, 1997.) 